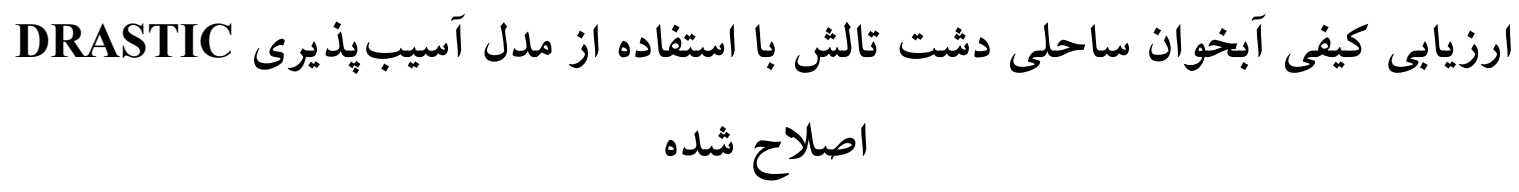

\author{
هيدى محموديور، سميه جنترستمى *، افشين اشرفزاده

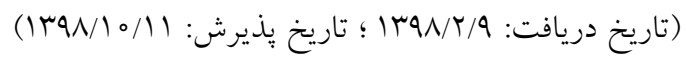

جكيده

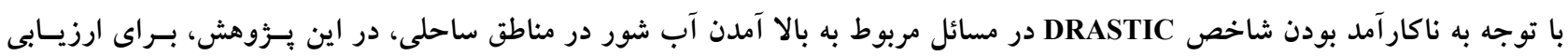

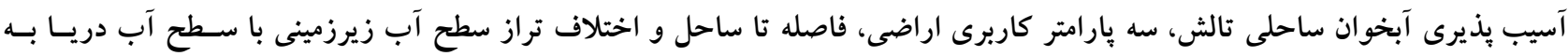

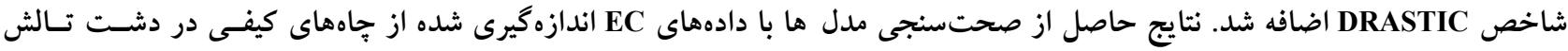

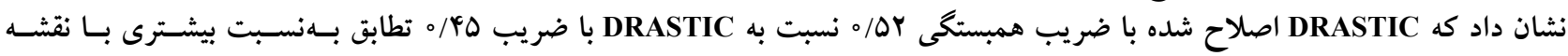

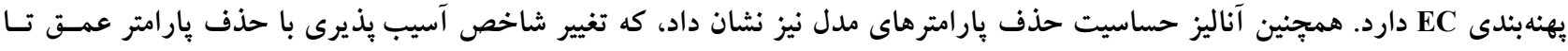

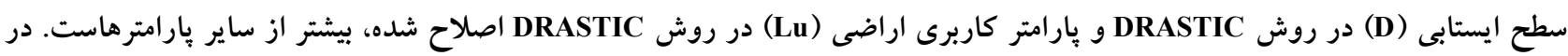

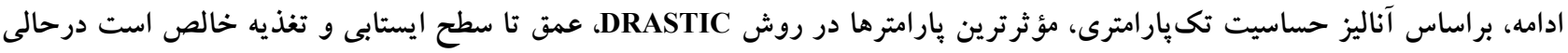

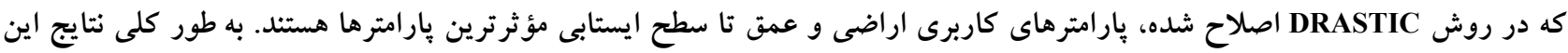

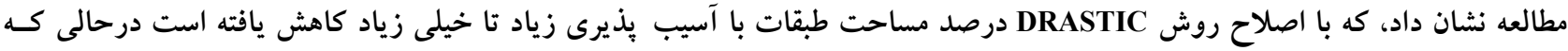

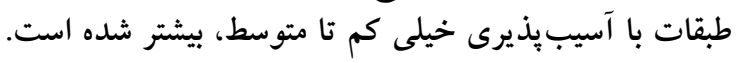

وازههاى كليدى: آناليز حساسيت، آب زيرزمينى، كاربرى اراضى، صحتسنجى 


$$
\text { جغر افيايى (GIS) يردازش مىشوند. }
$$

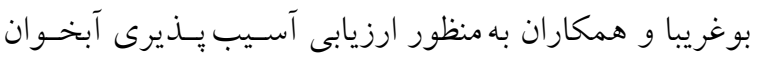
آنخد در كشور مراكش از مدل DRASTIC استفاده كردند. آنها

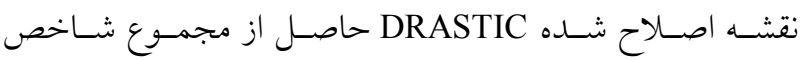

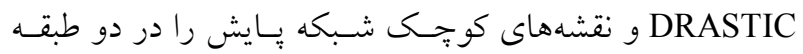

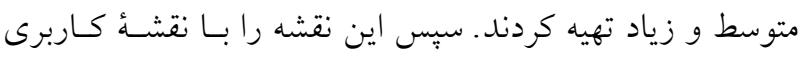

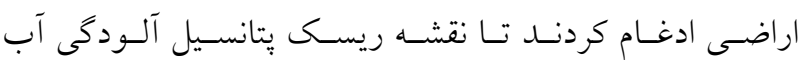

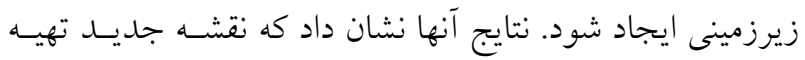
شده شامل سه طبقهبندى متوسط، زياد و خيلى زيـاد اسـت (9).

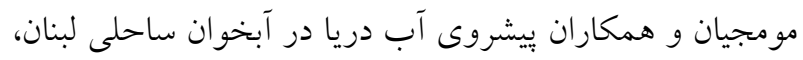
را با استفاده از روش DRASTIC و EPIK مورد ارزيسابى قـرار دادند. براى اين منظور، غلظت كل مواد جامد حل شـده (TDS)

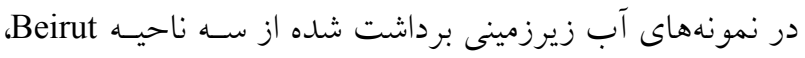
و و و Tal el Dibolip

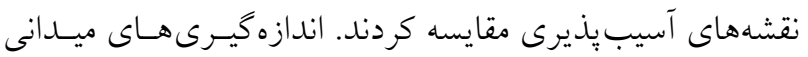

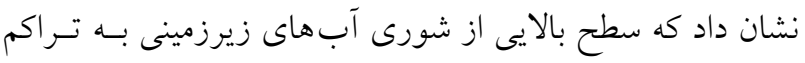

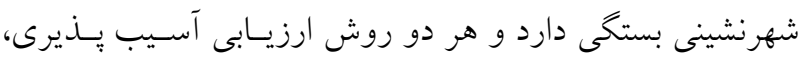
توانايى محدودى در رديابى نفوذ آب شور داشتند (0) (1). موندال

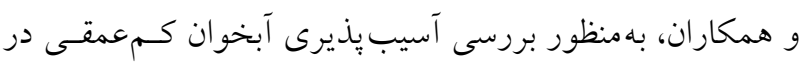

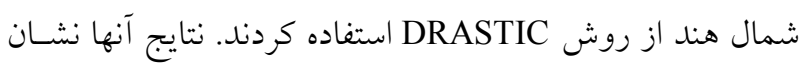

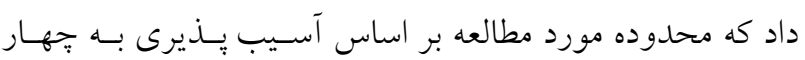

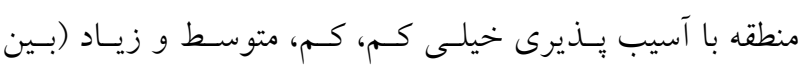

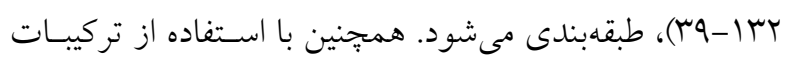

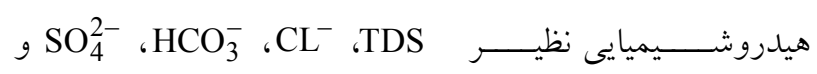
نشان داده شد كه QV درصــ از محــودهه مـورد $\mathrm{CL}^{-} / \mathrm{HCO}_{3}^{-}$ مطالعه در قسمت مركزى داراى آسيب يذيرى متوسط به بالاست

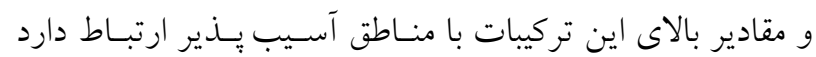

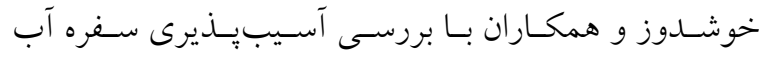

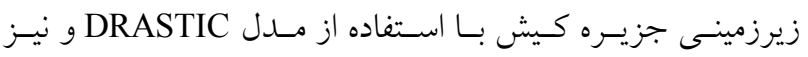
اصلاح آن براى شرايط سفره ساحلى جزيره كيش و مقايسه نتسايج

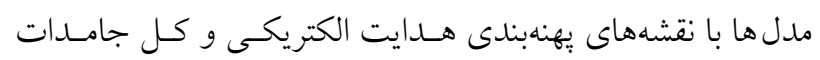

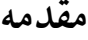

در بسـيارى از كشـورهاى جهـان، جمعيــت زيـادى در منــاطق

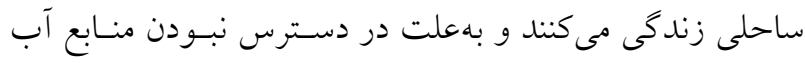

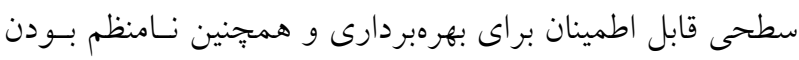

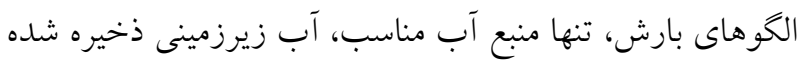

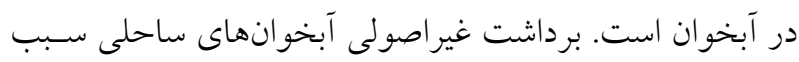

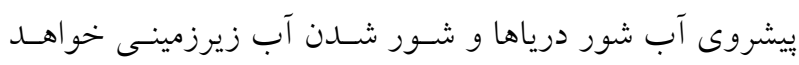

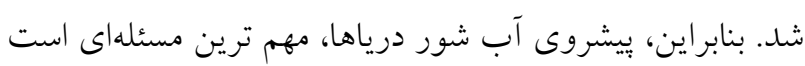

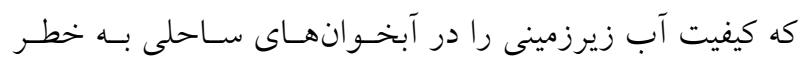

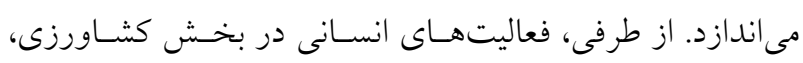

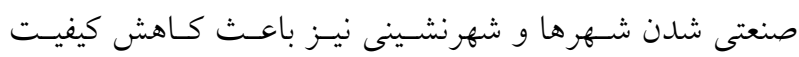
آبهاى زيرزمينى مىشود (9)

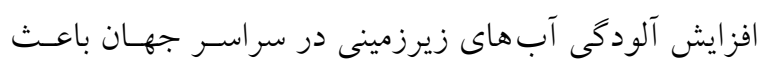

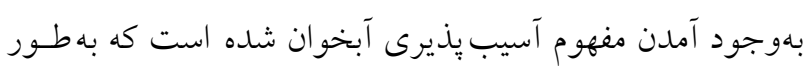

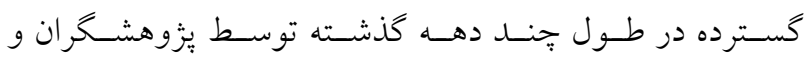

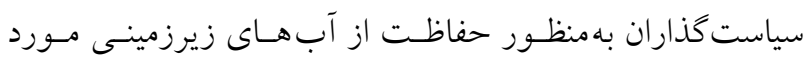

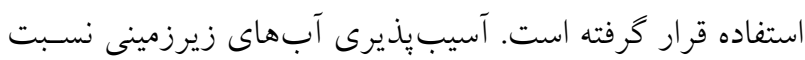

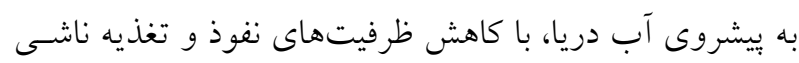

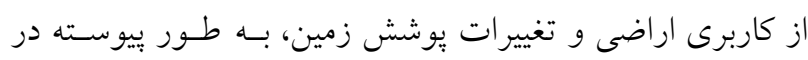

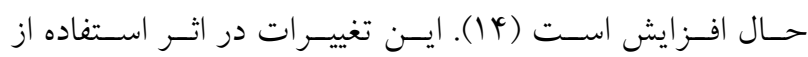

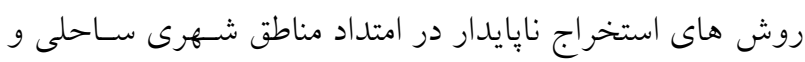
مناطقى كه رشد و افزايش جمعيت بيش از تغذيه طبيعى آبخوان

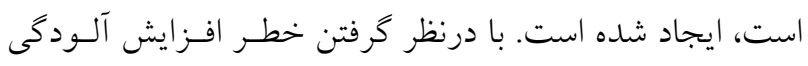

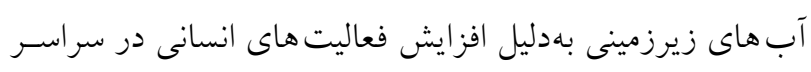

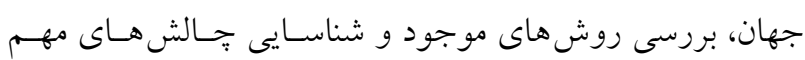

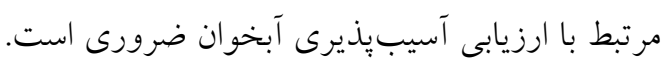

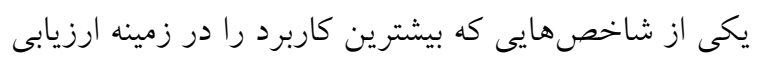

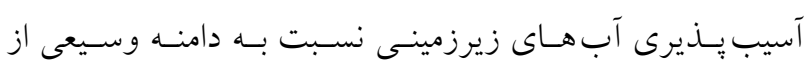

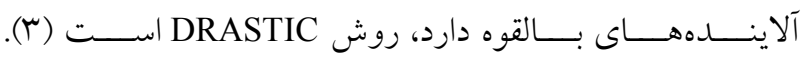

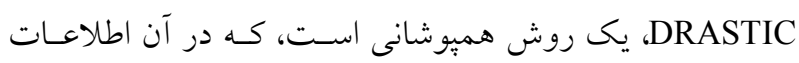

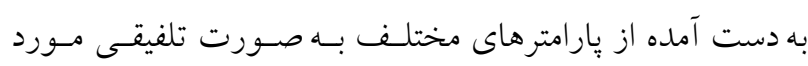

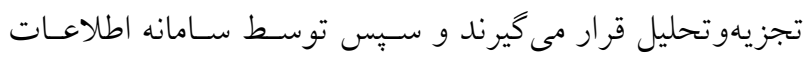


به بالا آمدن آب شور در مناطق ساحلى ناكارآمـــ اسـت (^)؛ از

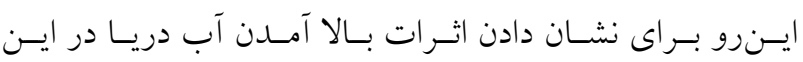

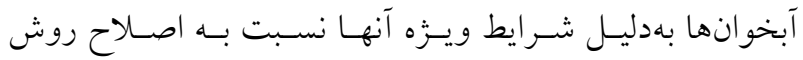

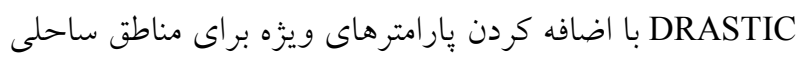

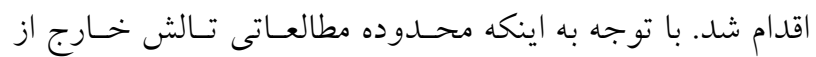

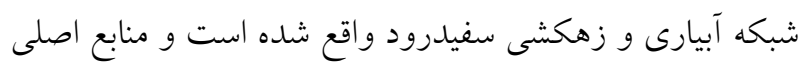

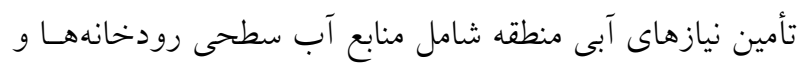

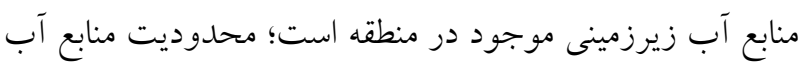

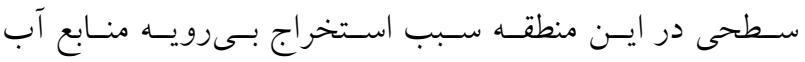

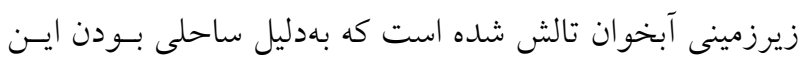

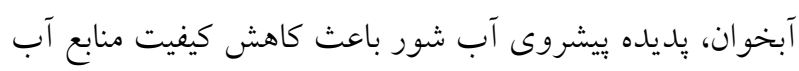

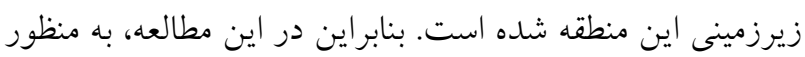

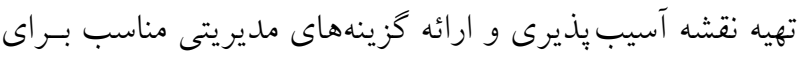

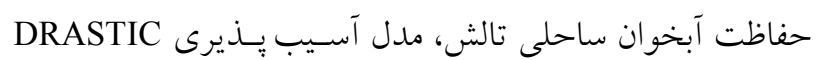
در اين منطقه مورد بررسى قرار مى گيرد. در ادامه، بـراى انطبـاق

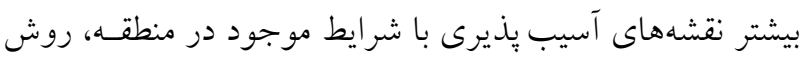

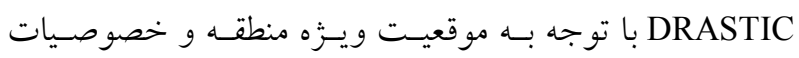

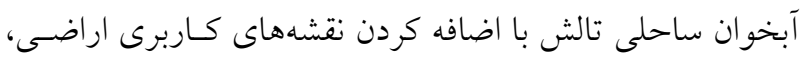

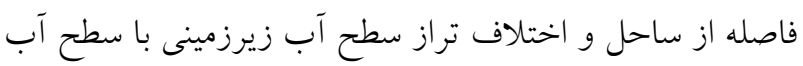

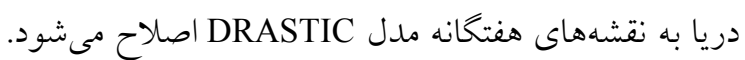

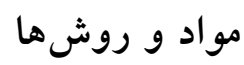

موقعيت منطقه مورد مطالعه

دشت تالش در شمال ايران و شمال غـرب اسـتان كـيلان قـرار

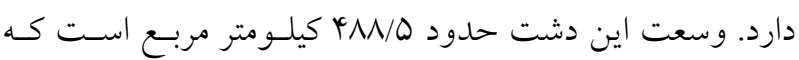
حدود 10/V درصد از كل محسدوده مطالعـاتى را دربـرمسى كيرد.

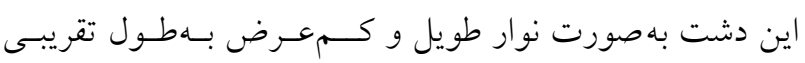

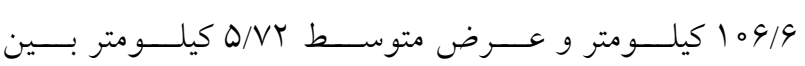

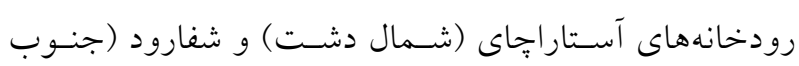

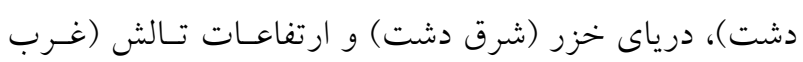

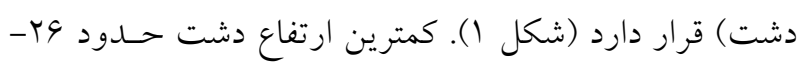

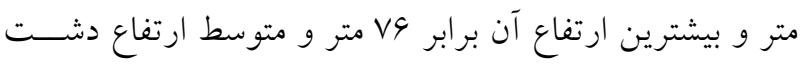

محلول (TDS) نشان دادند كه ميانخين اختلافها با نقشه هـدايت

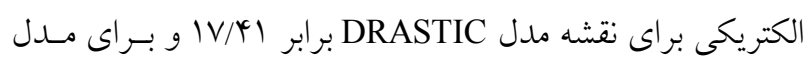

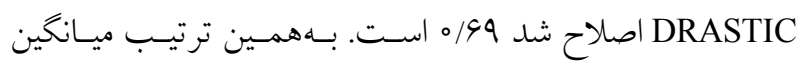

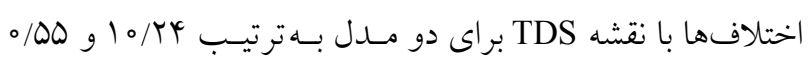
است كه در هر دو حالت حاكى از مطابقـت بيشـتر مـدل اصـلاح

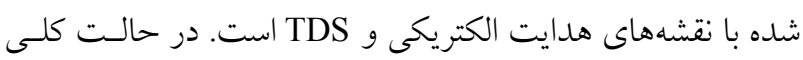

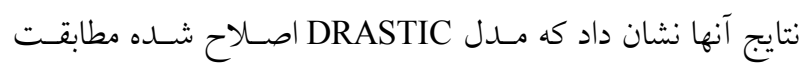
بيشـترى بـا دادههـاى مشـاهدهاى دارد (ه (). مهـدوى و زارع در

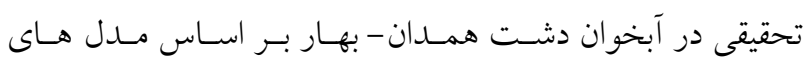

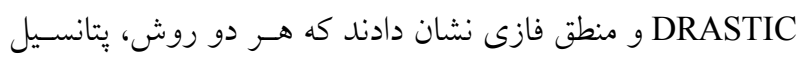

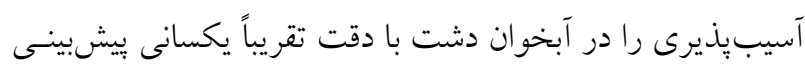

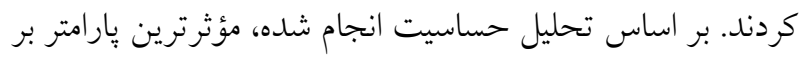

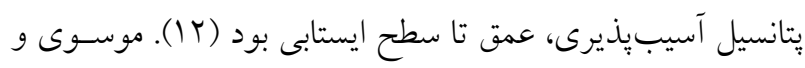

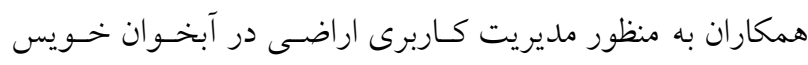

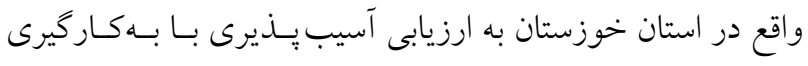

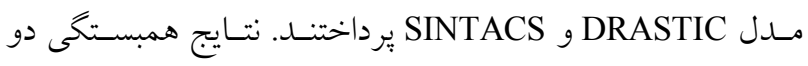

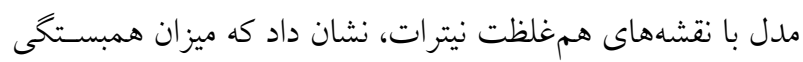

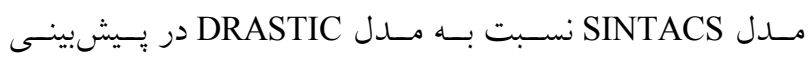

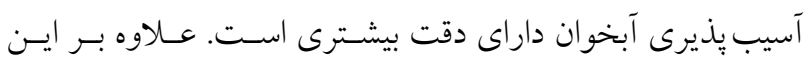

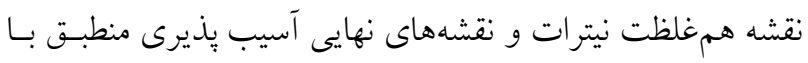

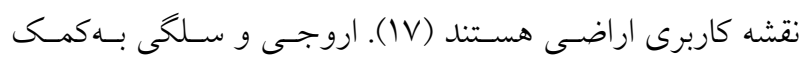

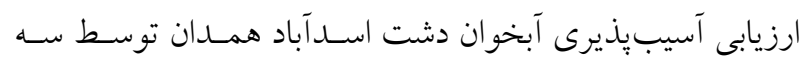

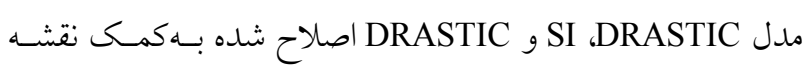
كاربرى اراضى، مشخص كردند كه هر سه مدل نقشـه يزهنسبنـدى

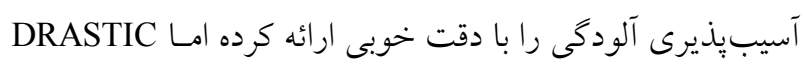

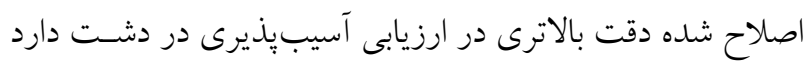

يكى از قابليتهاى مدل DRASTIC انعطاف يُّيرى زياد آن

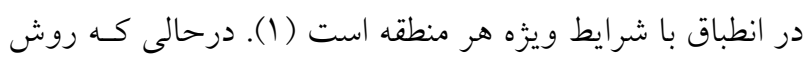

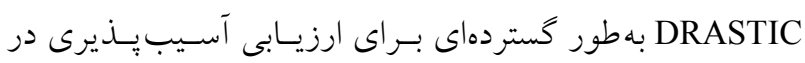

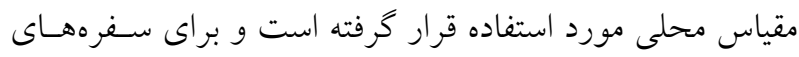

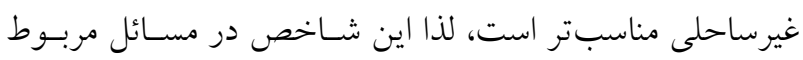




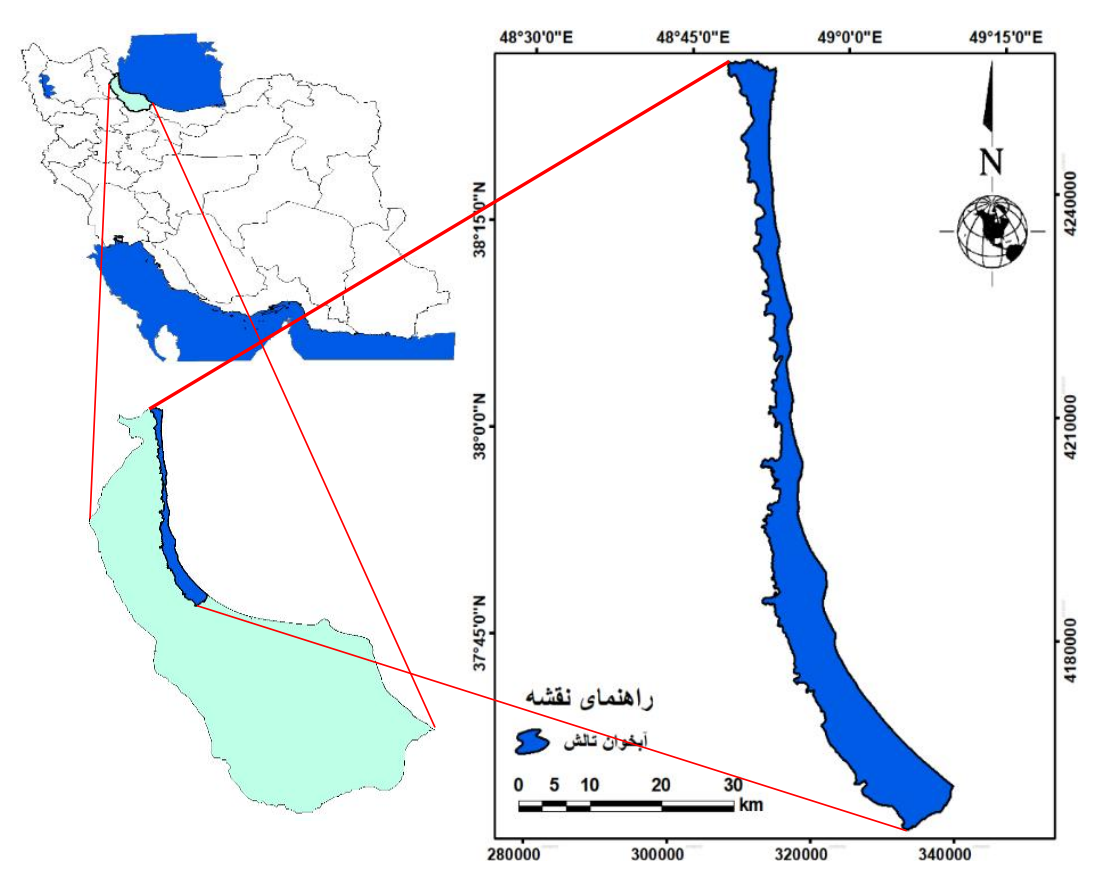

شكل ا. موقعيت منطقه مورد مطالعه

سنخ هاى دكر گونى مربوط به قبل از دوران اول و جوانتـرين سـازند

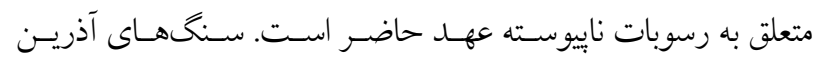

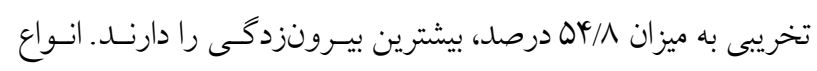
سنگهاى كربناته حدود 19/9 درصد است.

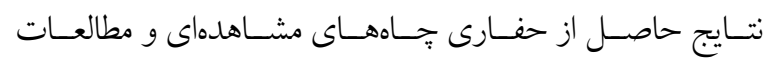

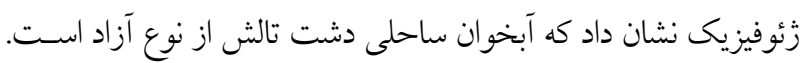

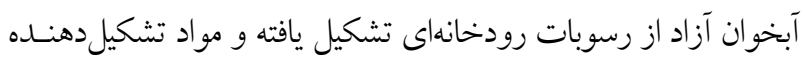

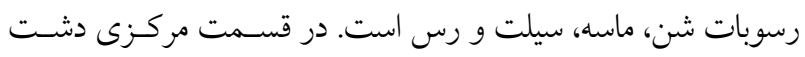

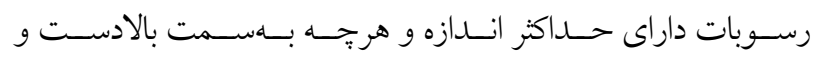

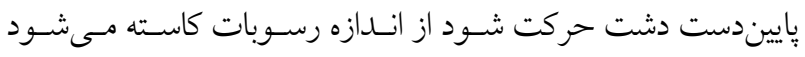

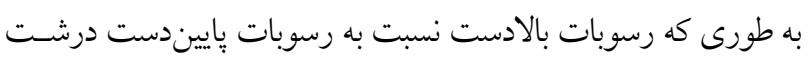

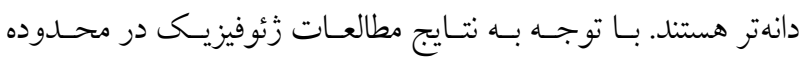

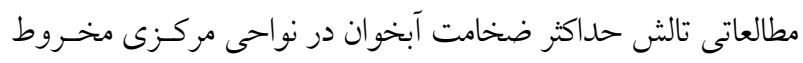

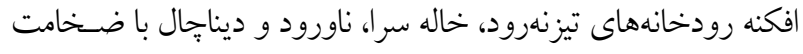

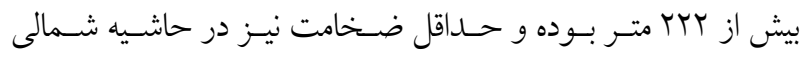

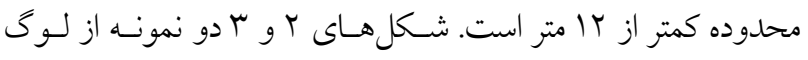

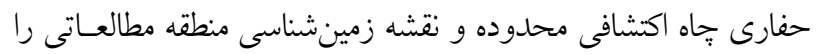
نشان مى دهد.
1/9V - متسر نسـبت بـه درياى آزاد است.

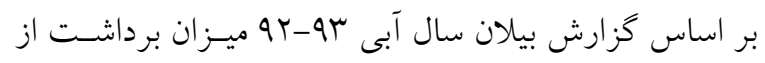

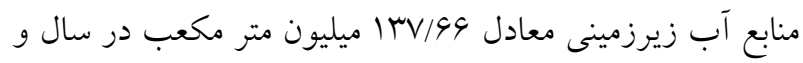

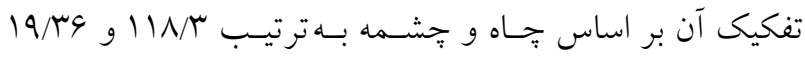

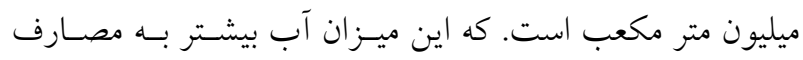

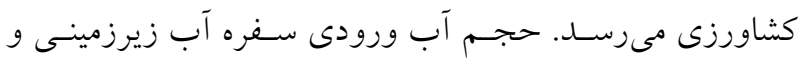
خروجى از آن برابر بوده و سفره در شرايط متعادل است.

\section{زمينشناسى و هيدروزئولوزى منطقه}

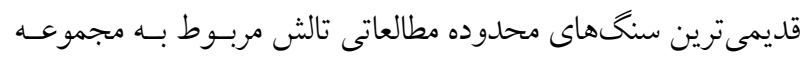

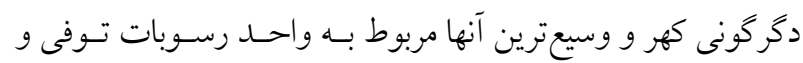

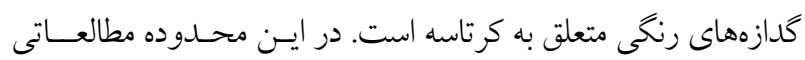

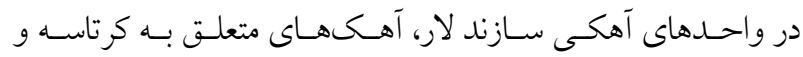

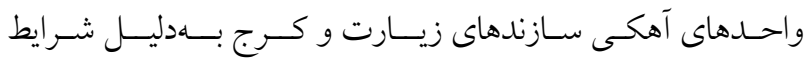
مساعد، آبخــوان كارستى تشـكيل شـــه اسـت. در ميـان سـازندهاى

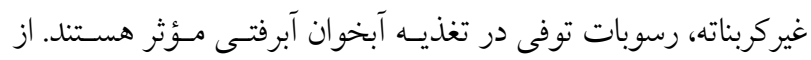

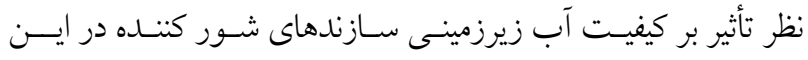

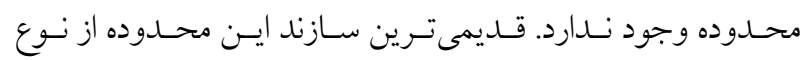




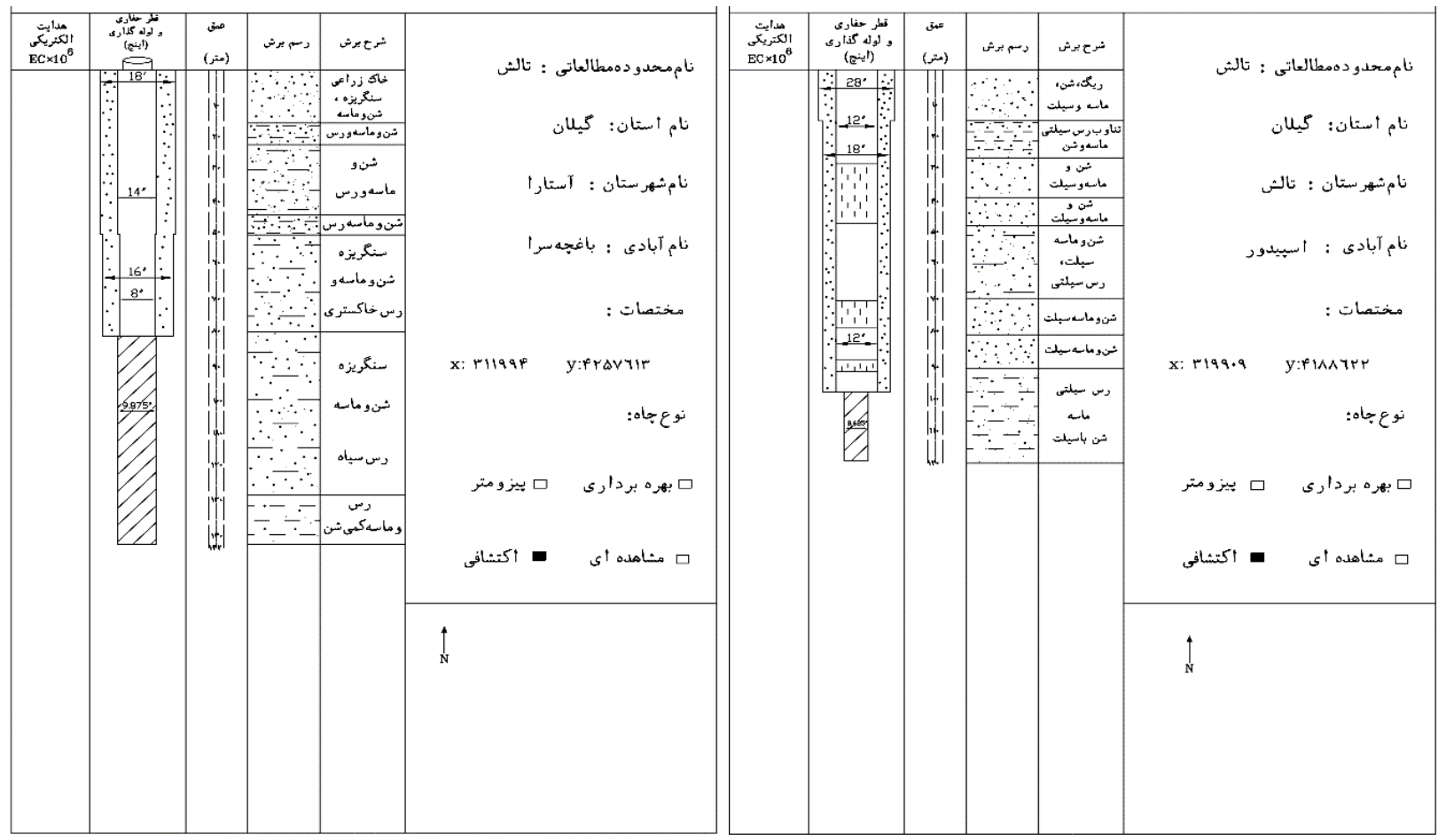

شكل ז. نمونه لو حى حفارى جاه اكتشافى

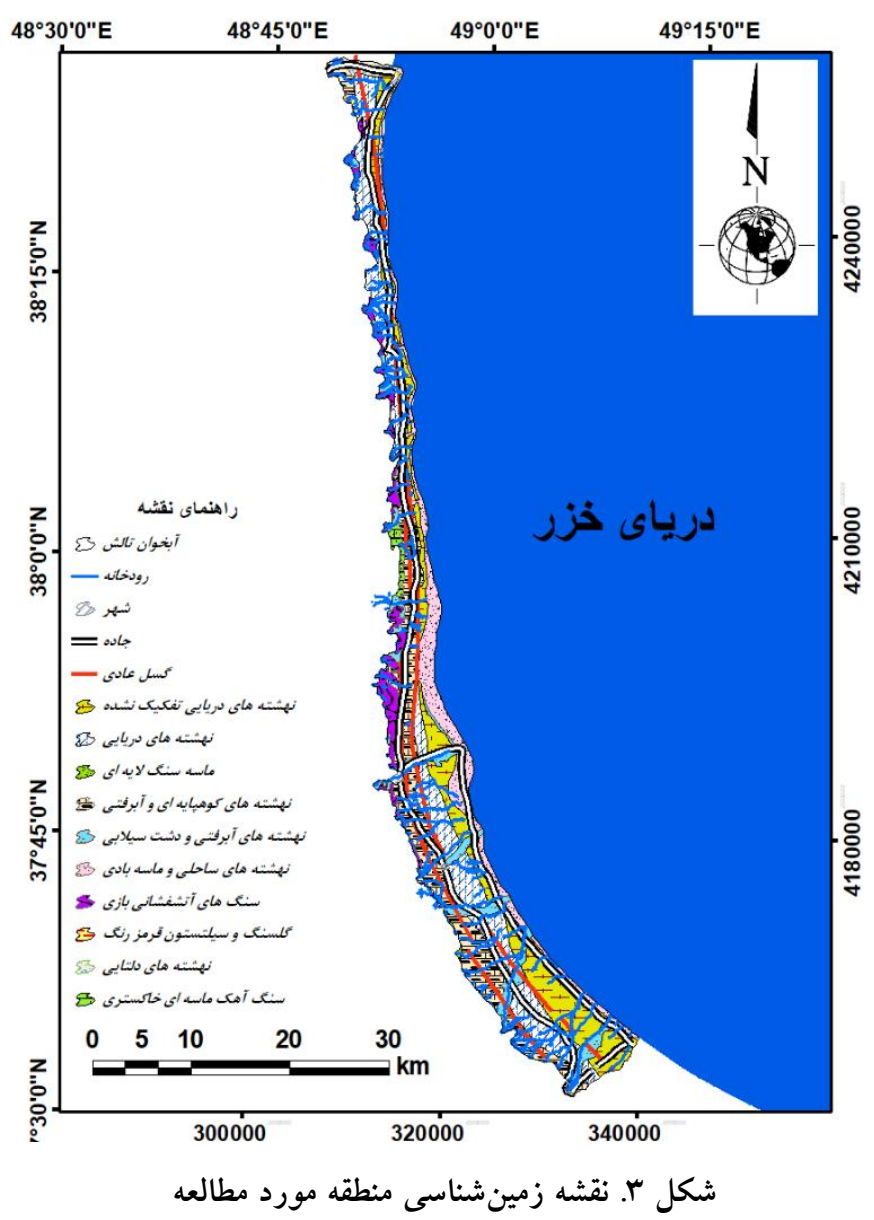




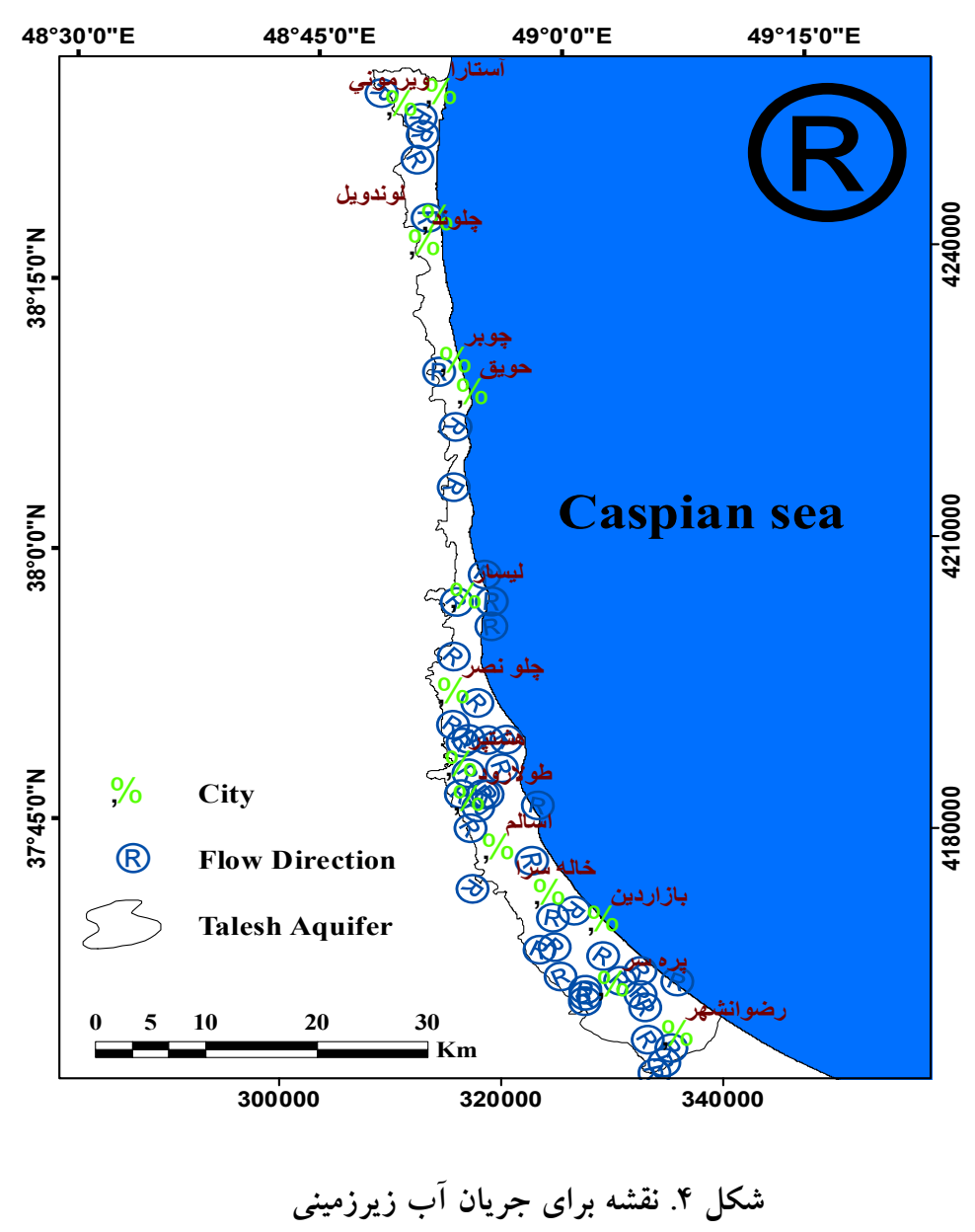

\section{آسيبِيذيرى بهروش DRASTIC}

عبارت آسيبِّيذيرى در هيدروزئولوزى براى اولين بار توسط

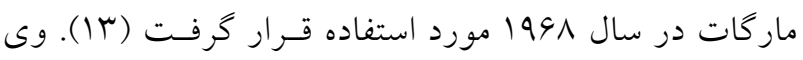

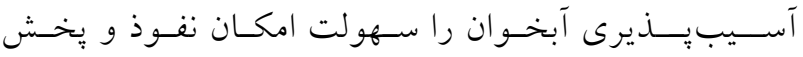

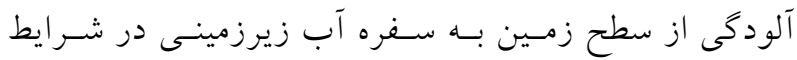

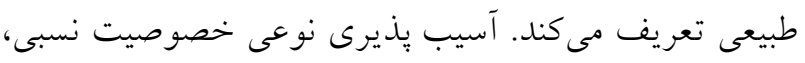

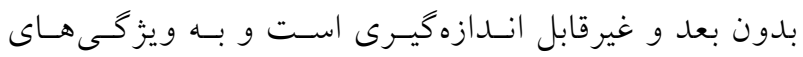

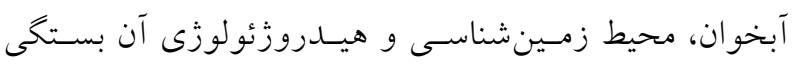
دارد (广).

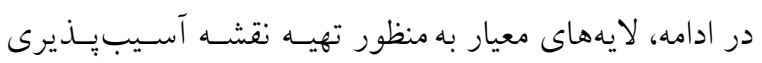
آبخوان در روش DRASTIC و مراحل آمادهسازى هر يكى ارائه

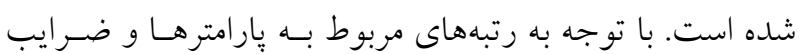

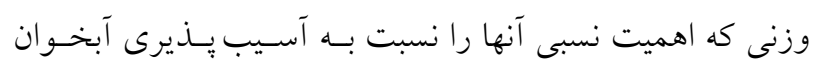

در اراضى برهسر واقع در جنوب دشـت رقـوم منحنسىهـاى تراز آب زيرزمينى بين M متر واقع در اراضى مخروط افكنهاى لومير تا وب- متر در اراضى ساحلى دشت متغير است حال آنكه

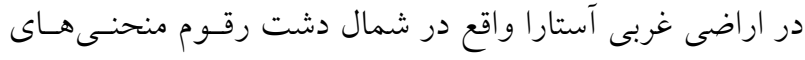

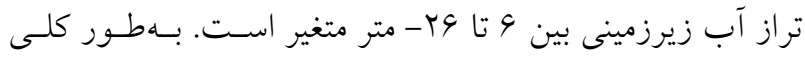

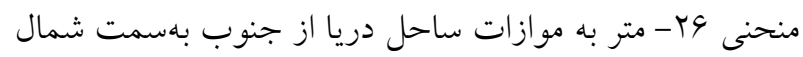

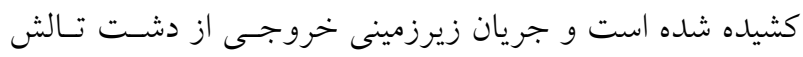

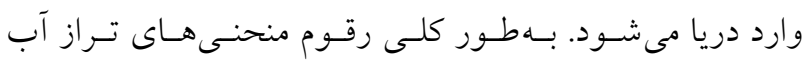

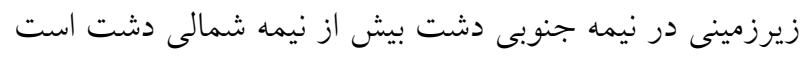

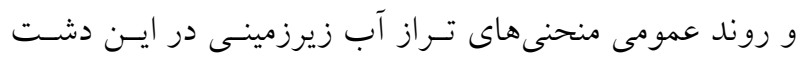

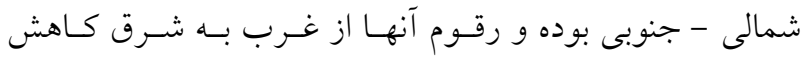

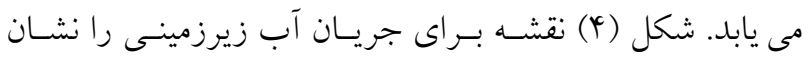
مى دهد. 
جدول ا. بازهها و رتبه هاى پارامترهاى شاخص DRASTIC و DRASTIC اصلاح شده (Y، r و V)

\begin{tabular}{|c|c|c|c|c|c|c|c|c|c|}
\hline \multirow{2}{*}{\multicolumn{2}{|c|}{ 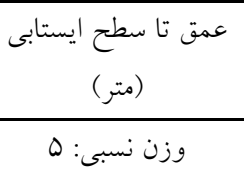 }} & \multicolumn{2}{|c|}{ (ميلى متر در سال خالص ) } & \multicolumn{2}{|l|}{ محيط آبخوان } & \multicolumn{2}{|c|}{ محيط خاى } & \multicolumn{2}{|c|}{ تويو گرافى } \\
\hline & & \multicolumn{2}{|c|}{ وزن نسبى: } & \multicolumn{2}{|l|}{ وزن نسبى: r } & \multicolumn{2}{|c|}{ وزن نسبى: ا } & \multicolumn{2}{|c|}{ وزن نسبى: 1} \\
\hline 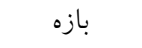 & 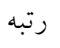 & بازه & 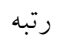 & 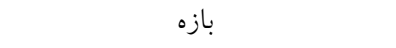 & رتبه & 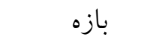 & رتبه & 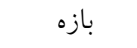 & 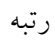 \\
\hline $0-1 / 0$ & 10 & $\cdot-\Delta \cdot / \Lambda$ & 1 & شن و ماسه & $\wedge$ & 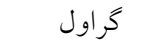 & 10 & $0-r$ & 10 \\
\hline $1 / 0-4 / 9$ & 9 & $00 / 1-101 / 9$ & r & ماسه همراه با مقدارى رس يا سيلت & 4 & ماسه & 9 & $r-9$ & 9 \\
\hline $4 / 9-9 / 1$ & v & $101 / 9-1 V V / A$ & 9 & رس و سيلت همر اه با مقدارى ماسه & r & لومى ماسهاى & 4 & $9-11$ & 0 \\
\hline $9 / 1-10 / 4$ & 0 & IVV/A-TOY & $\wedge$ & رس و سيلت & r & 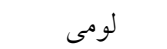 & 0 & $|r-| \Lambda$ & r \\
\hline $10 / Y-Y Y / 9$ & $r$ & $>Y Q Y$ & 9 & & & و ومى سيلتىرسى & r & $>11$ & 1 \\
\hline$r Y-Q-Y \circ / 0$ & r & & & & & & & & \\
\hline$>r \circ / 0$ & 1 & & & & & & & & \\
\hline \multirow{2}{*}{\multicolumn{2}{|c|}{ 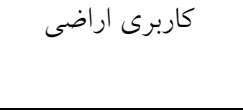 }} & \multirow{2}{*}{\multicolumn{2}{|c|}{ هدايت هيدروليكى (متر در روز) }} & \multirow{2}{*}{\multicolumn{2}{|c|}{ محيط غيراشباع }} & \multirow{2}{*}{\multicolumn{2}{|c|}{ زيرزمينى با آب دريا (متر) }} & \multirow{2}{*}{\multicolumn{2}{|c|}{ فاصله تا ساحل }} \\
\hline & & & & & & & & & \\
\hline \multicolumn{2}{|c|}{ وزن نسبى: ه } & \multicolumn{2}{|c|}{ وزن نسبى: r } & \multicolumn{2}{|l|}{ وزن ن وزبى: ه } & \multicolumn{2}{|c|}{ وزن وزنى: } & \multicolumn{2}{|c|}{ وزن نسبى: } \\
\hline 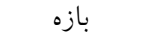 & 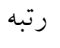 & بازه & رتبه & بازه & رتبه & 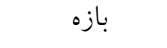 & رتبه & 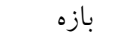 & رتبه \\
\hline شهرى & 9 & $<\varphi$ & 1 & كراول و ماسه & 10 & $<r$ & 10 & $<100$ & 10 \\
\hline 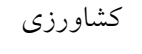 & v & $r-1 t$ & r & ماسه و كراول همراه كمى سيلت و رس & 9 & $r-r$ & $\wedge$ & $100-Y_{0} 0$ & 9 \\
\hline 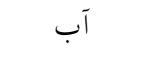 & o & $\mid Y-Y \Lambda$ & $r$ & ماسه و كراول همر اه با سيلت & $\wedge$ & $4-9$ & 4 & r००-r०o & $\wedge$ \\
\hline \multirow[t]{7}{*}{ 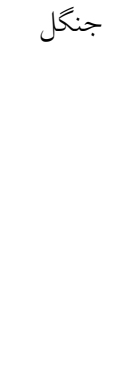 } & $r$ & $r \Lambda-r_{0}$ & 4 & رس و سيلت همراه با مقدار كمى & v & $9-9$ & 0 & YoO-Y०o & V \\
\hline & & $\varphi \circ-\Lambda \circ$ & $\wedge$ & ماسه - اسه & & $9-10$ & r & $\forall \circ \circ-\infty \circ \circ$ & 4 \\
\hline & & $10-100$ & 9 & & & $10-Y_{0}$ & r & $000-900$ & $\Delta$ \\
\hline & & $>100$ & 10 & & & $>r_{0}$ & 1 & $900-100$ & r \\
\hline & & & & & & & & $100-1000$ & r \\
\hline & & & & & & & & $1000-r_{0} \circ 0$ & r \\
\hline & & & & & & & & $>r \circ o$ & 1 \\
\hline
\end{tabular}

از اين پيارامترها هستند. عمق تا سطح ايستابى (Depth to groundwater table): در دشت تالش رقوم منحنى هاى همعمق آب زيرزمينى بين ه/ه تـا

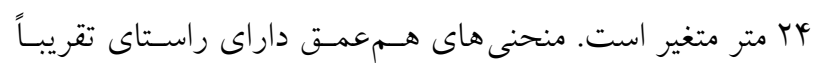
شمالى - جنوبى بوده و رقوم آنها از غرب بهسمت شرق كاهش مى يابد. در اراضى مخروط افكنهاى عمـق سـطح آب زيرزمينسى بيش از ه ا متر است كه بهسمت دريا كاهش يافته و در اراضسى ساحلى آبخوان آبرفتى به كمتر از r متر مىرسد. وسعت نواحى با عمق برخورد به سطح آب زيرزمينى كمتر از ا، بين ا تـاس بو
نشـان مسىدهــ (جــدول ()، نقشـهـ شـاخص آسـيبـــيرى DRASTIC بر اساس رابطه ا محاسبه مىشود: DRASTIC Index $=\mathrm{D}_{\mathrm{r}} \mathrm{D}_{\mathrm{w}}+\mathrm{R}_{\mathrm{r}} \mathrm{R}_{\mathrm{w}}+\mathrm{A}_{\mathrm{r}} \mathrm{A}_{\mathrm{w}}+$

$$
\mathrm{S}_{\mathrm{r}} \mathrm{S}_{\mathrm{W}}+\mathrm{T}_{\mathrm{r}} \mathrm{T}_{\mathrm{w}}+\mathrm{I}_{\mathrm{r}} \mathrm{I}_{\mathrm{w}}+\mathrm{C}_{\mathrm{r}} \mathrm{C}_{\mathrm{w}}
$$

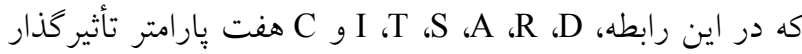
بـــر آســيبـــــيرى آب زيرزمينــى هســتند كــه در سيسـتم هيدروزئولوزيكى كنتـرل كنــده آلـودكى آب زيرزمينسى وجـود آنس

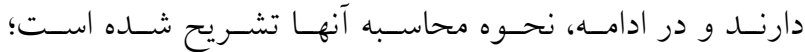
انديسهاى W و نيز به ترتيب نشاندهنده وزن و رتبه هر يـك 


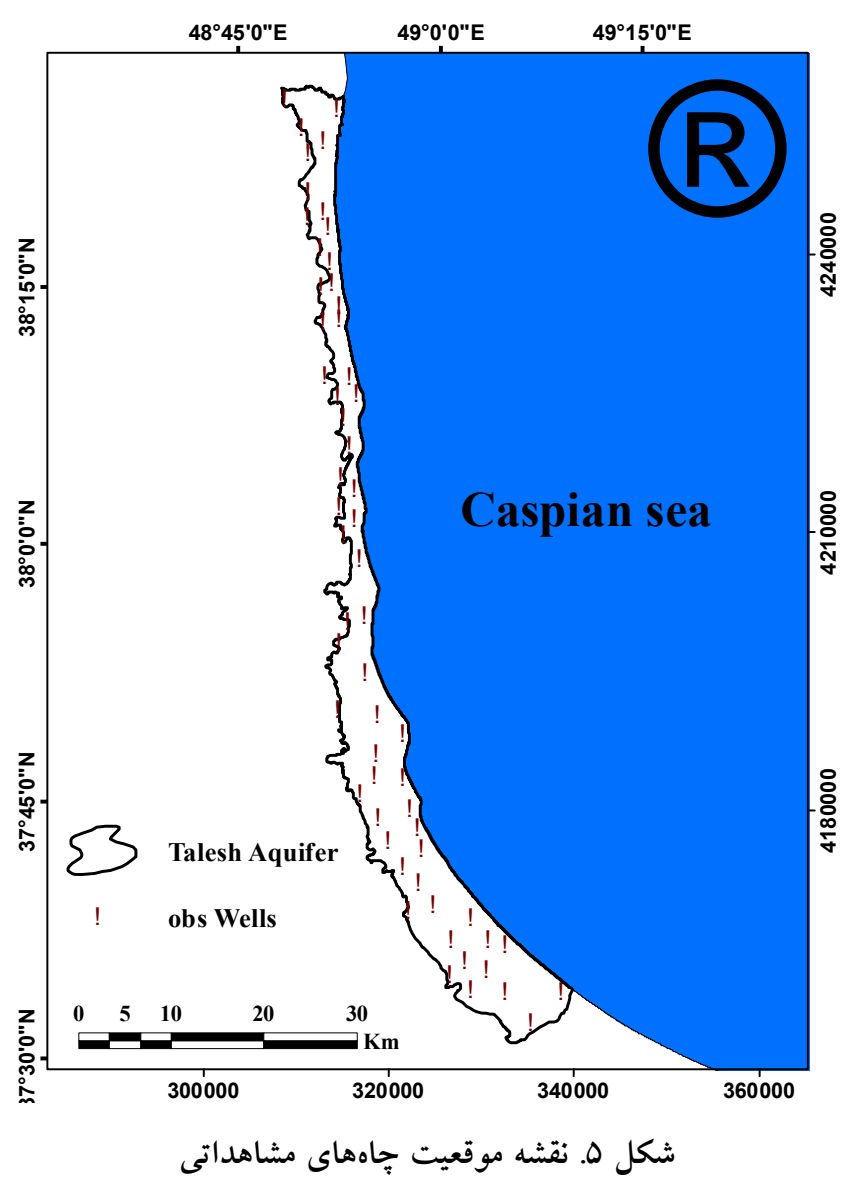

زيرزمينى ورودى به آبخوان تأثيرى در انتقال آلودكى از سطح به عمق ندارد، لذا مقدار جريان ورودى زيرزمينس (معـادل كF/TY

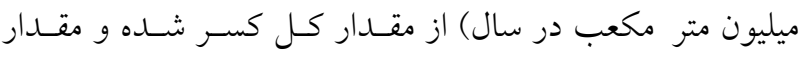

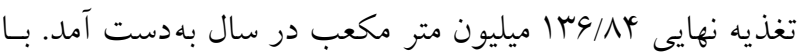

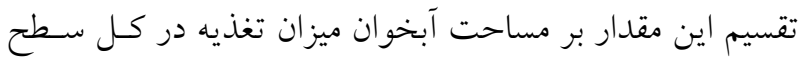

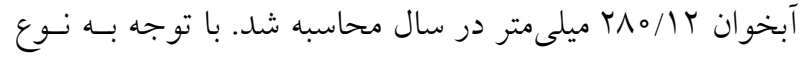
بافت خاك، محيط غيراشباع و هدايت هيدروليكى آبخـوان ايسن ميزان تغذيه براى نقاط مختلف يكسـان نبـوده و در هـر منطقـهـ

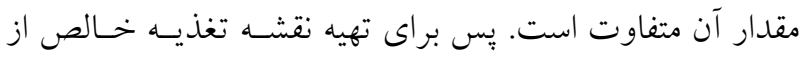

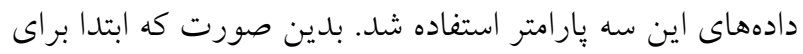

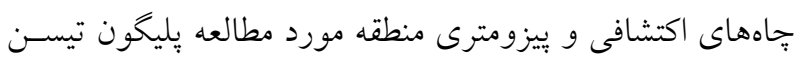

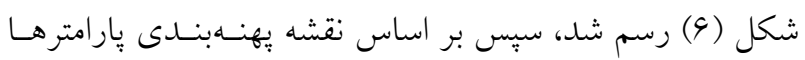

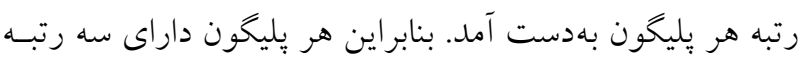

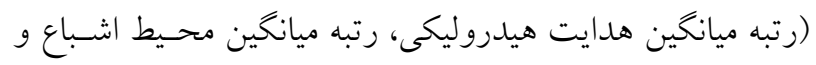

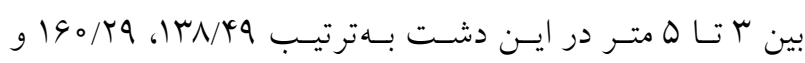

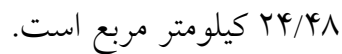
براى تهيه نقشه عمق تا سطح ايستابى، از دادهــاى ماهانـه

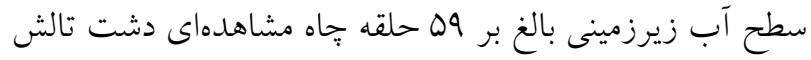

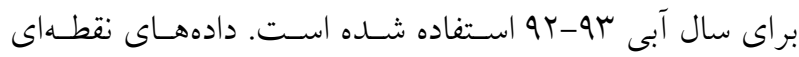

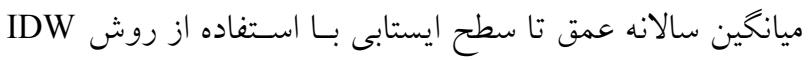

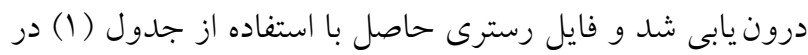

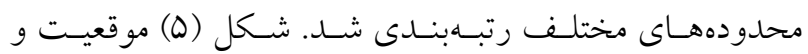
ير اكنش مكانى قّاههاى مشاهداتى را نشان مىدهد.

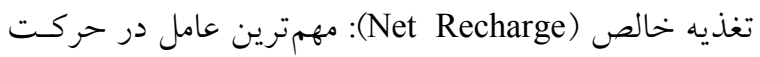

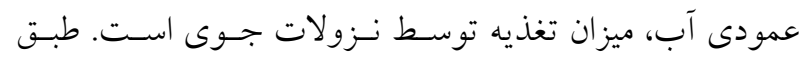

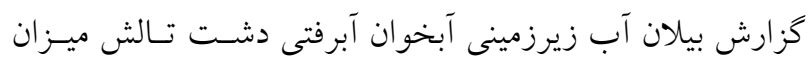

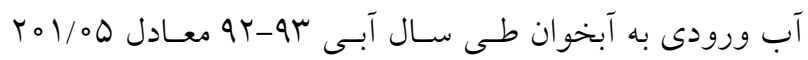

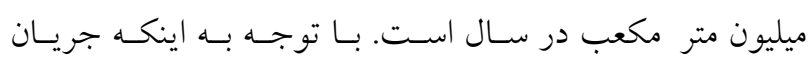




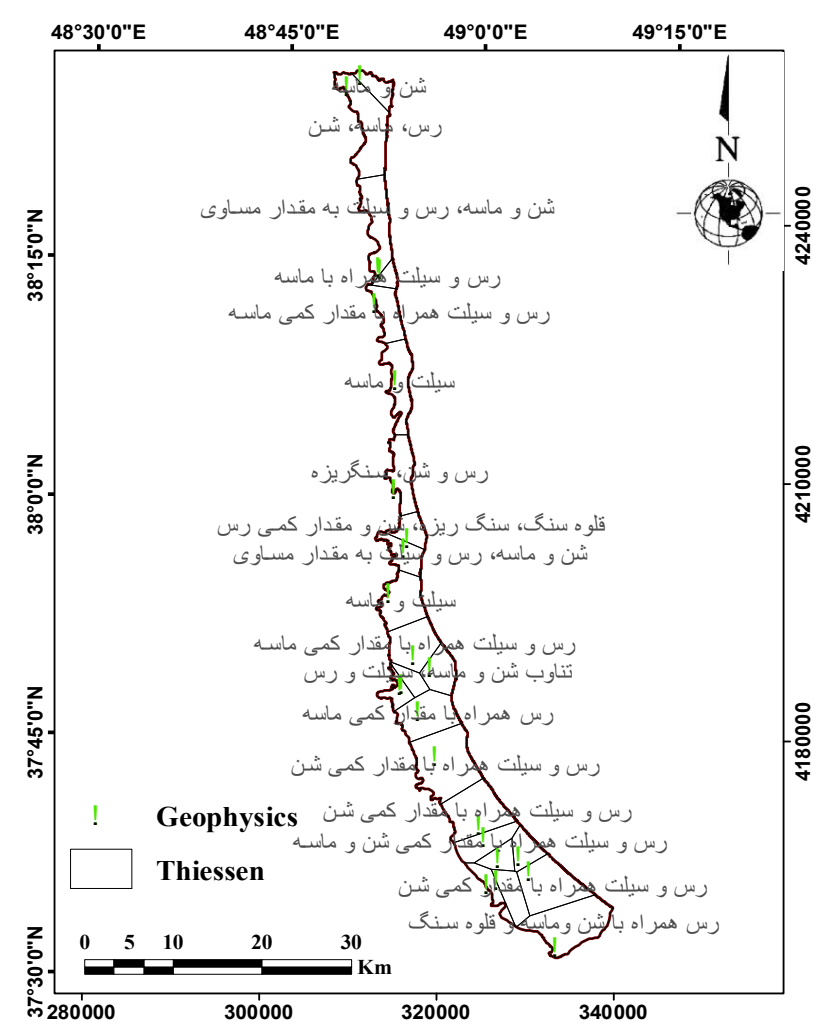

شكل 9. نقشه بِليكون تيسن جاههاى اكتشافى و بيزومترى منطقه مورد مطالعه

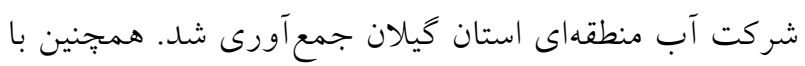

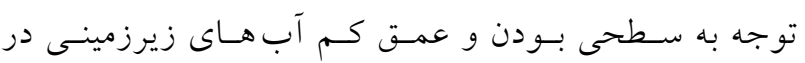

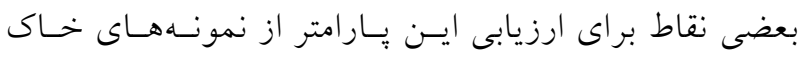

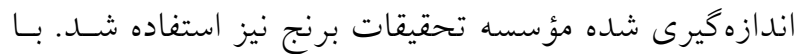

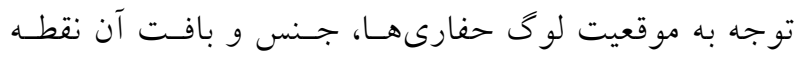

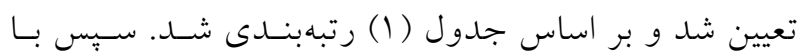

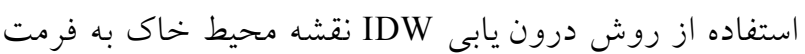
رسترى تهيه شد. تويوگر افى (Topography): براى تهيه لايه تويـوكرافى از نقشـهـ

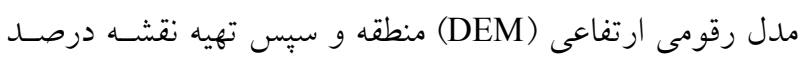

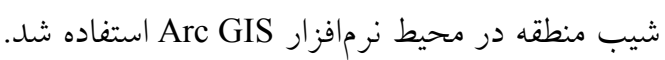
محسيط غيراشـباع (Impact of Vadose Zone): بـر ایى تهيـهـ

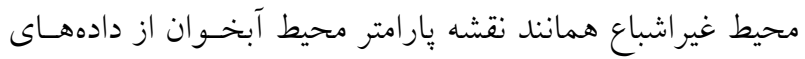

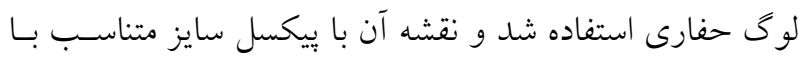

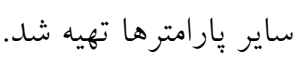

رتبه ميانخين محيط خاك) بوده و در ادامه با حاصل ضـرب ايسن

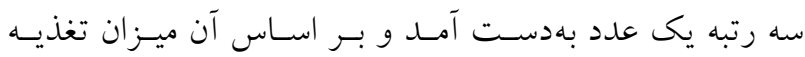

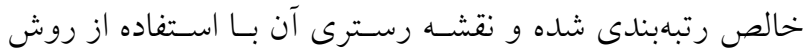

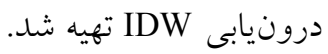
محيط آبخوان (Aquifer media): بـراى تهيـه نقشـه محيط آبخوان دشت تالش از كاوشهاى زيرسطحى (لوى حفارىهاى

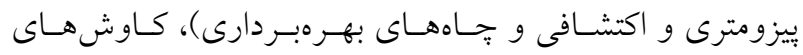
زئوفيزيكى و زمينشناسى منطقه مورد مطالعه استفاده شد. بدين صورت كه برحسب نسبت جنس مواد تشكيل دهنده آبخو ان در

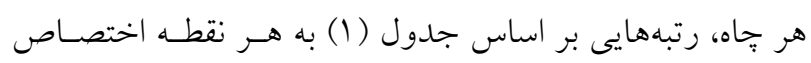

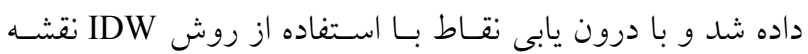

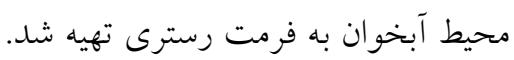

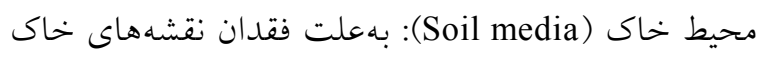

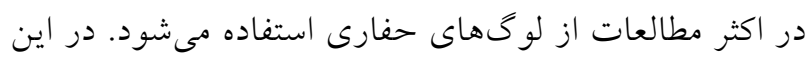

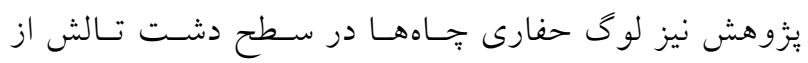


يلى گَون محدوده مورد نظر بهعنوان نوار سـاحلى درنظـر كرفتـه.

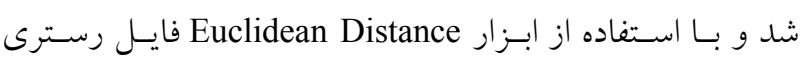

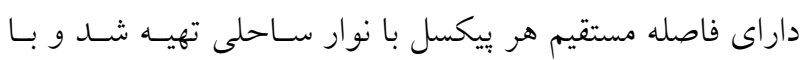
استفاده از جدول (1) رتبهبندى شد.

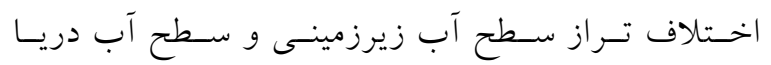

:(Height of groundwater level of above sea level)

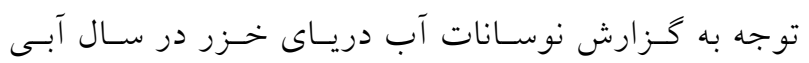

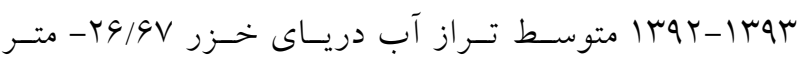

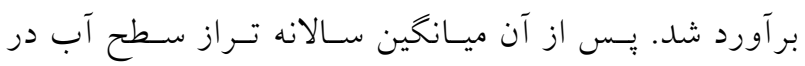

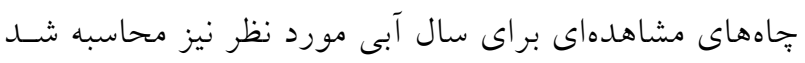

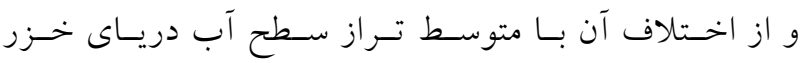

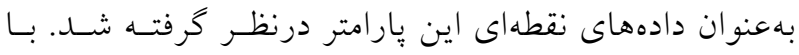

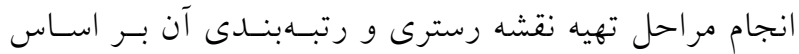

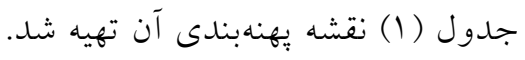

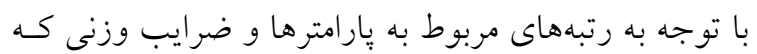

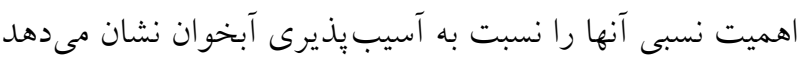

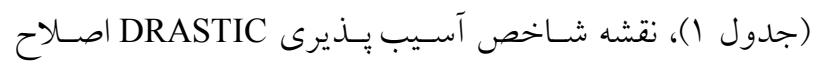

شده، بر اساس رابطه Y محاسبه مىشود: DRASTIC Index $=\mathrm{D}_{\mathrm{r}} \mathrm{D}_{\mathrm{w}}+\mathrm{R}_{\mathrm{r}} \mathrm{R}_{\mathrm{w}}+\mathrm{A}_{\mathrm{r}} \mathrm{A}_{\mathrm{w}}+\mathrm{S}_{\mathrm{r}} \mathrm{S}_{\mathrm{w}}+$

$$
\begin{aligned}
& \mathrm{T}_{\mathrm{r}} \mathrm{T}_{\mathrm{w}}+\mathrm{I}_{\mathrm{r}} \mathrm{I}_{\mathrm{w}}+\mathrm{C}_{\mathrm{r}} \mathrm{C}_{\mathrm{w}}+\mathrm{Di}_{\mathrm{r}} \mathrm{Di}_{\mathrm{w}}+ \\
& \mathrm{Le}_{\mathrm{r}} \mathrm{Le}_{\mathrm{w}}+\mathrm{Lu}_{\mathrm{r}} \mathrm{Lu}_{\mathrm{w}}
\end{aligned}
$$

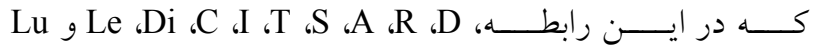

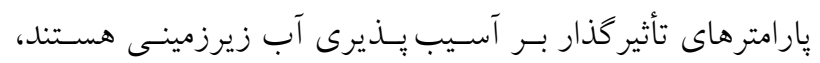

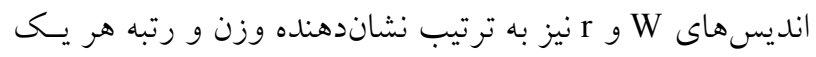

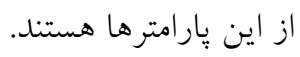

\section{آناليز حساسيت}

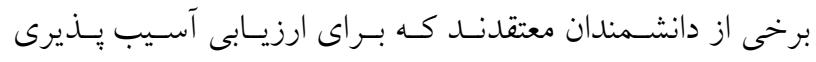

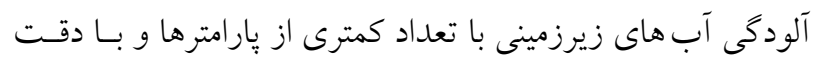

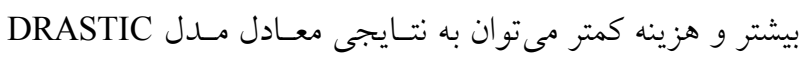
دست يافت (ه). براى ارزيابى مدل و كسـب اطلاعـات از اثـرات
هدايت هيدروليكى (Hydraulic Conductivity): اطلاعـات

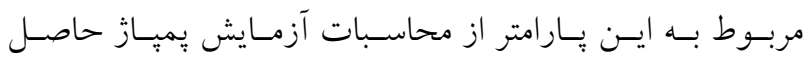

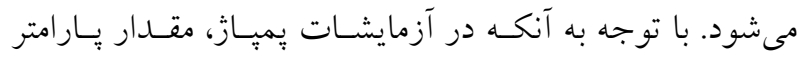

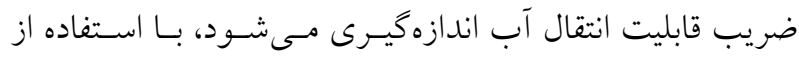

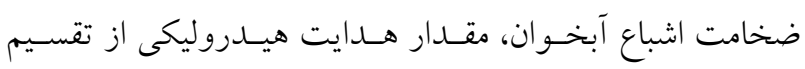

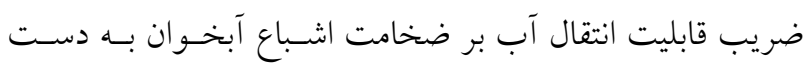
آمد. اطلاعات و نقاط جغر افيايى مربوط به ضريب قابليت ابناليت انتقال

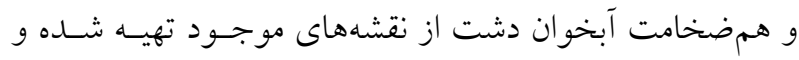
كليـه مراحـل تهيـه نقشـه مطـابق بارامترهـاى قبلـى در محسيط تمان Arc GIS

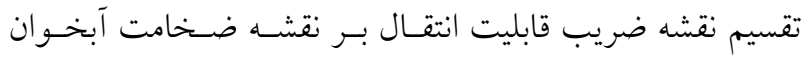
نقشه هدايت هيدروليكى دشت بهدست آمد.

\section{آسيب:ذيرى بهروش DRASTIC اصلاح شده}

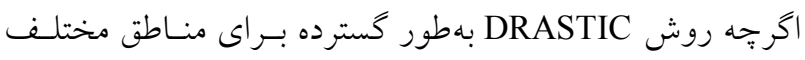

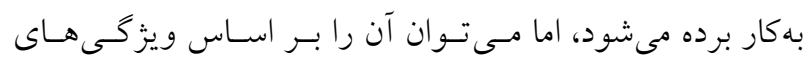

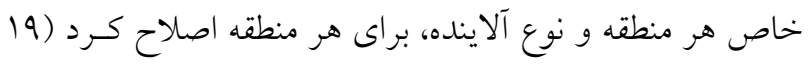

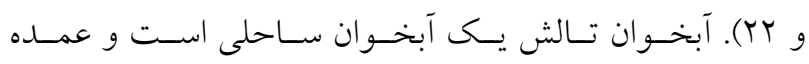

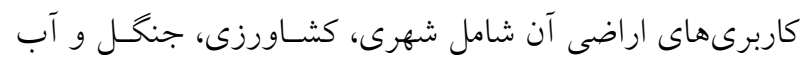

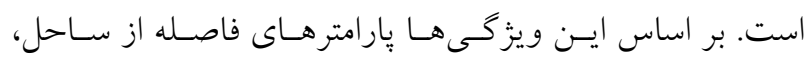

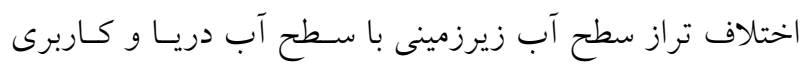

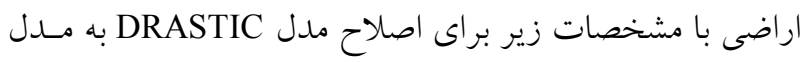

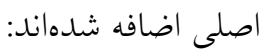
كاربرى اراضى (Land use): بــاى تهيـه نقشـهـ كـاربرى

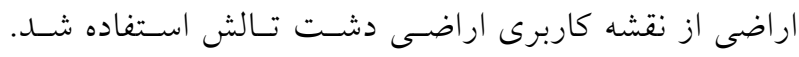

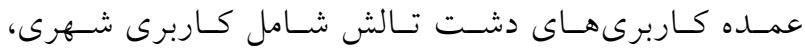
كشـاورزى، آب و جنَــل اسـت. :-هس از مشـخص كـردن كاربرىها در محدوده مطالعاتى رتبهبندى براى هـر كـاربرى بر اساس جدول (1) انجام شد. بقيه مراحل تهيـه ايسن نقشـهـ همانند يار امترهاى قبلى انجام شد. فاصله تا ساحل (Distance from the shoreline): تهيه نقشه

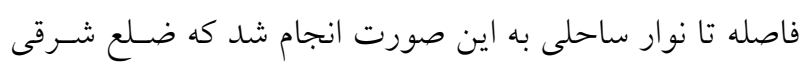


آناليز حساسيت تك بارامترى (يارامتر واحد) آناليز حساست تكى بارامترى توسط نايوليتـانو و فبـرى در سـال

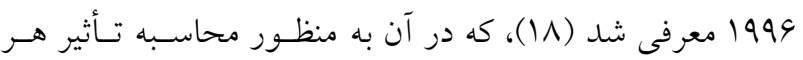

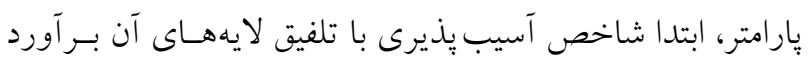

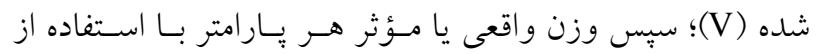

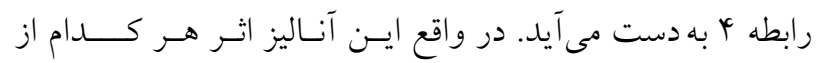

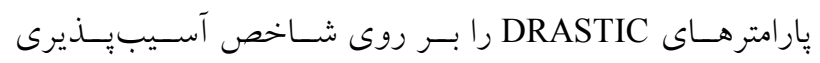

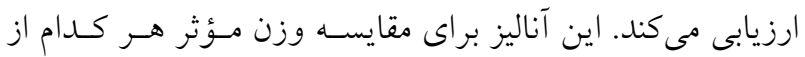

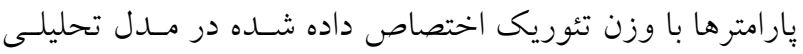

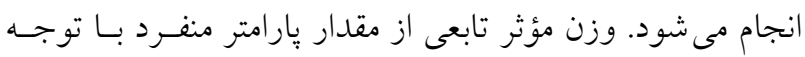

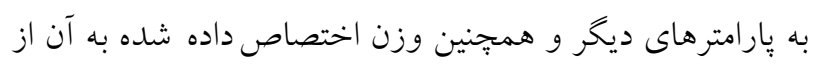

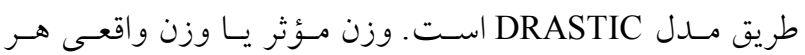
بارامتر با اسـتفاده از رابطه ب محاسبه مى شعود: $\mathrm{S}=\left(\mathrm{P}_{\mathrm{r}} \mathrm{P}_{\mathrm{w}} / \mathrm{V}\right) \times 100$

در اين رابطه W وزن مؤثر هر بارامتر و Pr و Pw به ترتيب رتبـه

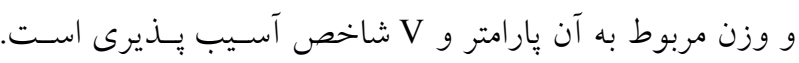

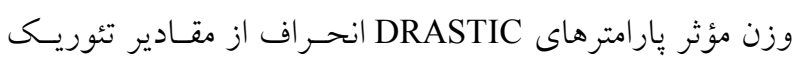
آنها را نشان مى مدوند.

صحتسنجى مدل يكى از روشهاى اعتبارسنجى شاخصهاى مدآسيب يـــيرى اسـتفاده از

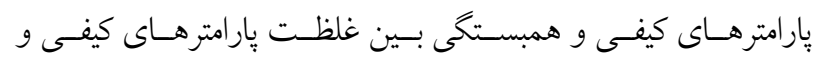
شاخص محاسبه شده است. با توجه به موقعيت جغرافيايى و سـاحلى

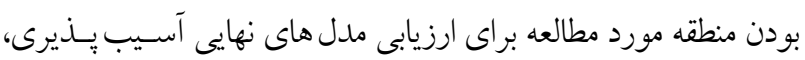

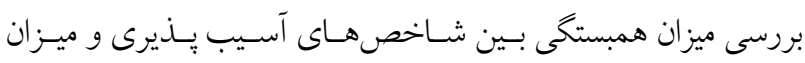

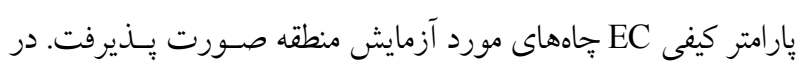

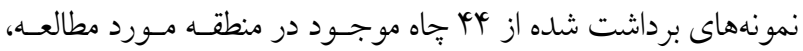
نقشه توزيع غلظت EC بهدست آمد. با توجـهـ بـه شـكل (V) ميـزان

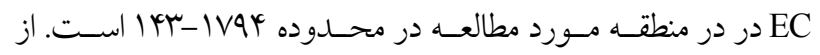

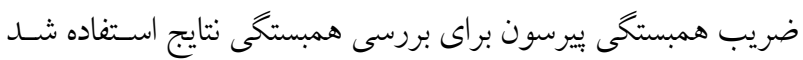

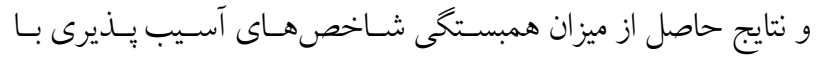
يارامتر كيفى در جدول (Y) آورده شده است.
مقادير رتبه و وزن اختصاص يافتـه بــه يارامترهـاى ورودى مــدل

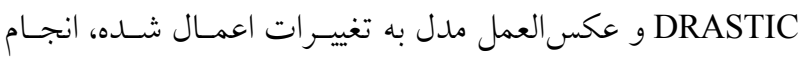

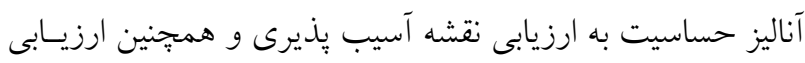

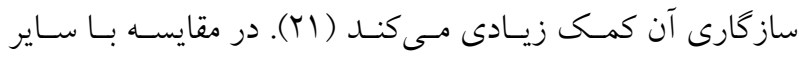

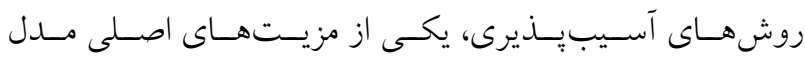

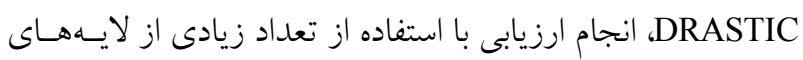
دادههاى ورودى است كه اعتقاد بر اين است كه اتخرات خطاهـا و عدم قطعيتهاى بارامتر منفرد در خروجى نهايى محدود مى شود. برخى نيز معتقدند كه وزنها و رتبههاى مـورد استفاده در مـدل،

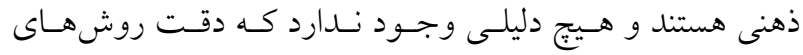

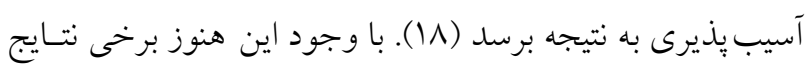
اين مدل را در غياب شواهد تجربى حمايت مى كنند.

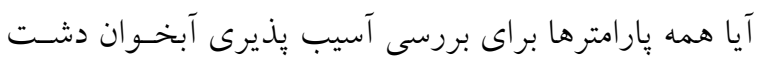

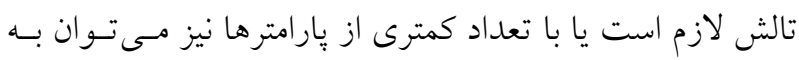
نتيجه مطلوب دست يافت؟ نتيجه اين صحتسنجى بـا استفاده از آناليز حساسيت روشهاى مورد استفاده، مشـخص مسى دئسود. دو نوع آناليزحساسيت در اين تحقيق انجام شده است:

آناليز حساسيت حذف نقشه اين آناليز كه براى اولين بار توسط لودويك و همكاران در سـال

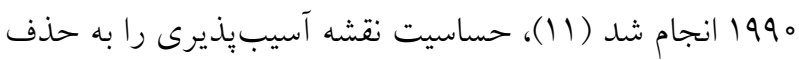

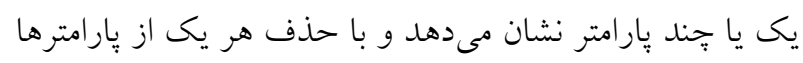

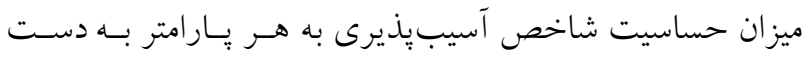
مى آيد. اين آناليز از طريق رابطه ب محاسبه مىشودئ $\mathrm{S}=(|\mathrm{V} / \mathrm{N}-\mathrm{V} / \mathrm{n}| / \mathrm{V}) \times 100$

در ايسن رابطـه، S ميـزان حساسـيت را نشـان مسيدهــ؛ V و v به ترتيب شاخص آسيب يذيرى بدون حذف و و با حذف بـ بـارامتر؛ N $n$ و تعداد لايههاى مورد استفاده براى محاسبه V و V هستند.

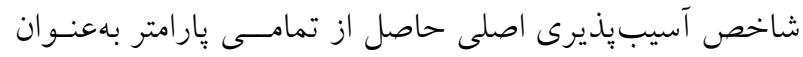

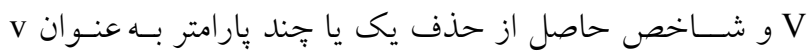
درنظر كرفته مى مود. 


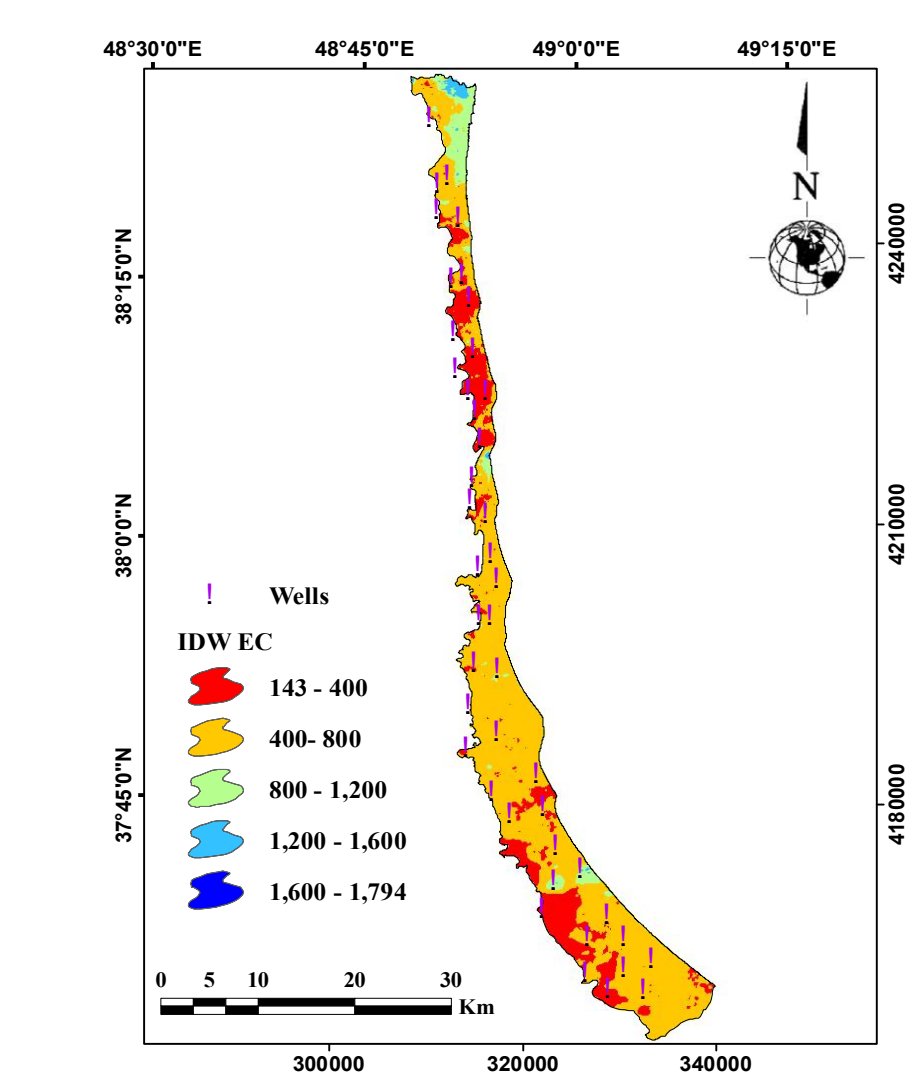

شكل V. الف) نقشه بِهنهبندى EC و موقعيت جاههاى اندازهيرى بارامترهاى كيفى

جدول r. همبستخى بين غلظت يارامتر EC و شاخصهاى آسيبذيرى DRASTIC و DRASTIC اصلاح شده

\begin{tabular}{|c|c|c|}
\hline \multirow[b]{2}{*}{ يارامتر كيفى } & \multicolumn{2}{|c|}{ ضريب تبيين (R') } \\
\hline & DRASTIC & DRASTIC اصلاح شده \\
\hline $\mathrm{EC}$ &.$/ 4 Q$ &.$/ Q T$ \\
\hline
\end{tabular}

بين

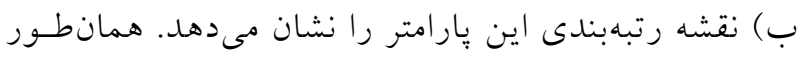
كه مشاهده مى شود؛ قسمت شمالى و مركزى محدوده مورد

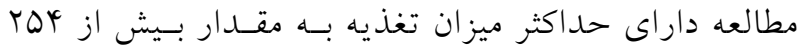

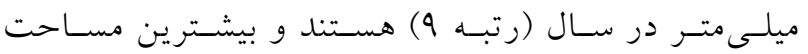
محدوده آبخوان را بهخود اختصاص داده است.

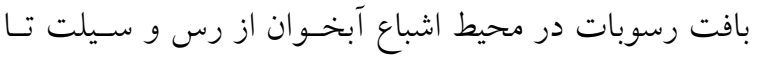
شن و ماسه متغير است. مناطق با بافت شن و ماسهاى بيشسترين

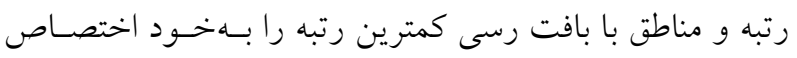

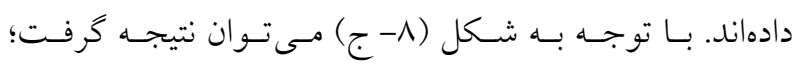

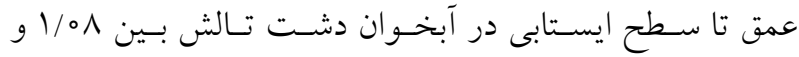

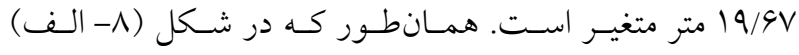
ملاحظه مىشود، بيشـترين مسـاحت آبخـوان داراى عمـق بـين

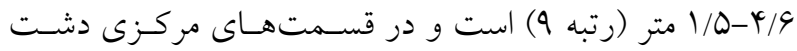

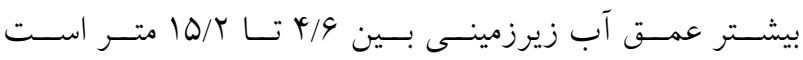

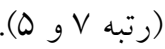
با توجه به نوع بافت خاك، محيط غير اشـباع و هـدايت

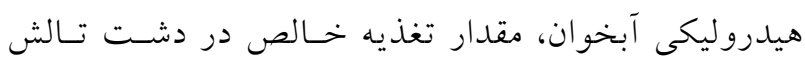



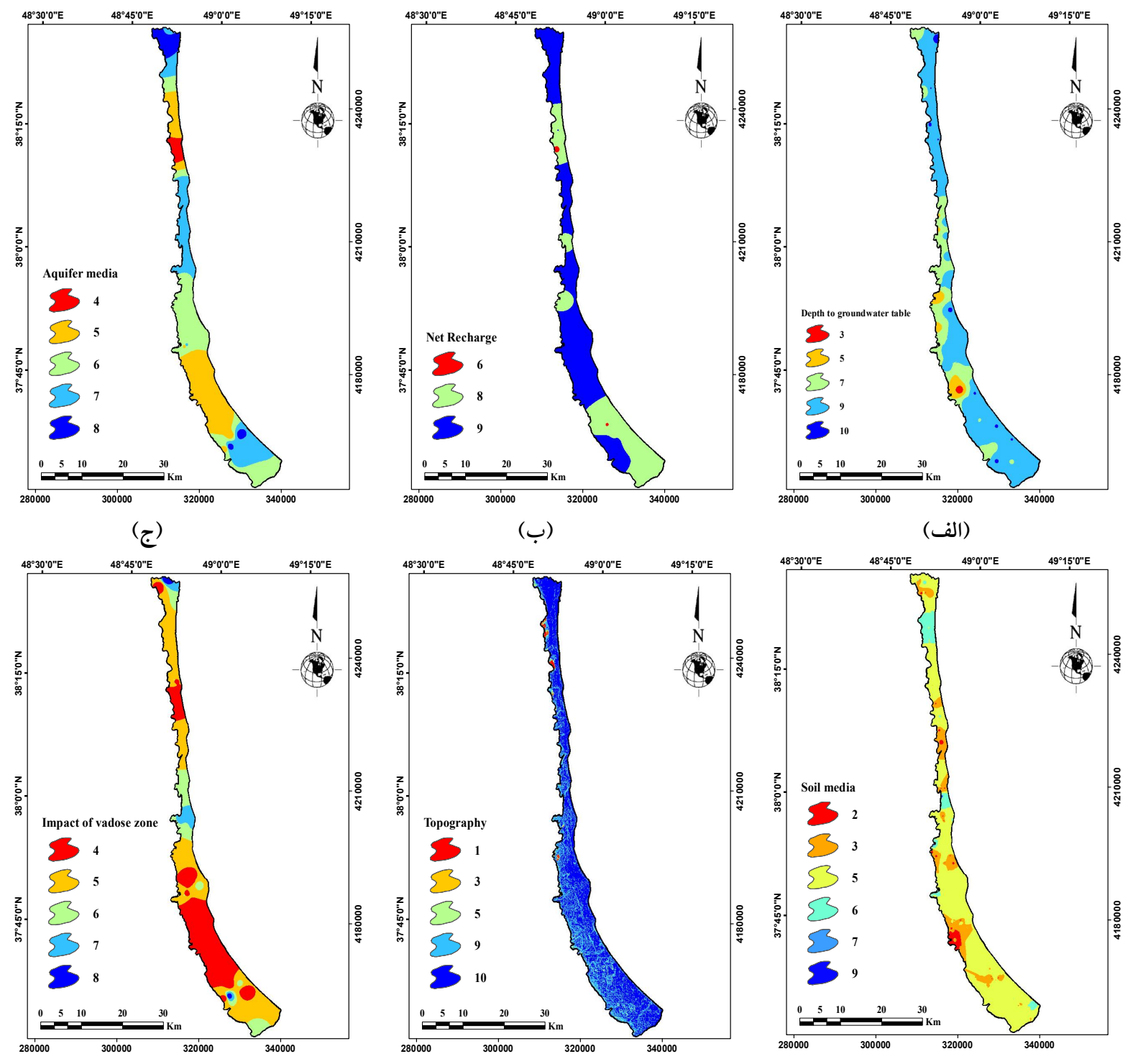

(०)

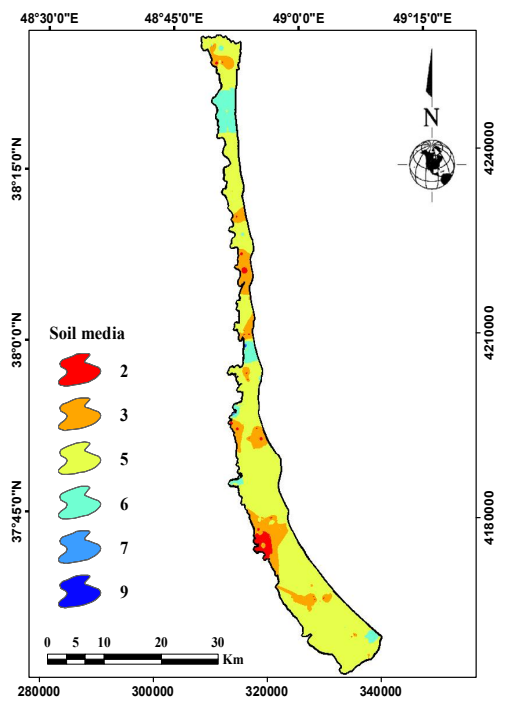

(3)

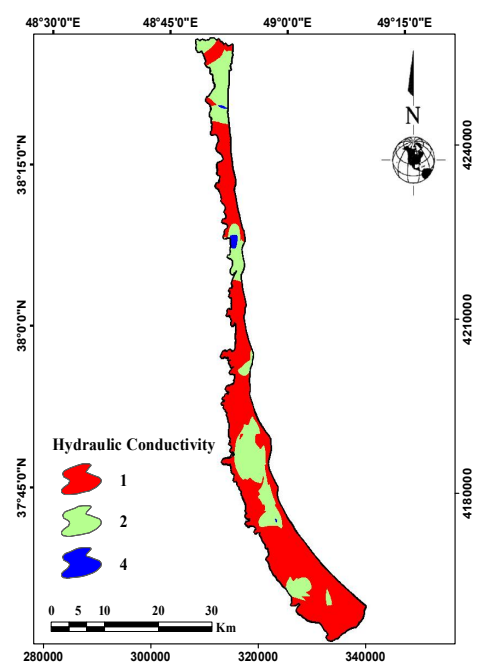

(j)

شكل ^ـ نقشهاى: الف) عمق تا سطح ايستابى، ب) تغذيه خالص، ج) محيط آبخوان، د) محيط خاك، ه) تويوكر افى، و) محيط غيراشباع و ز) هدايت هيدروليكى إخى 


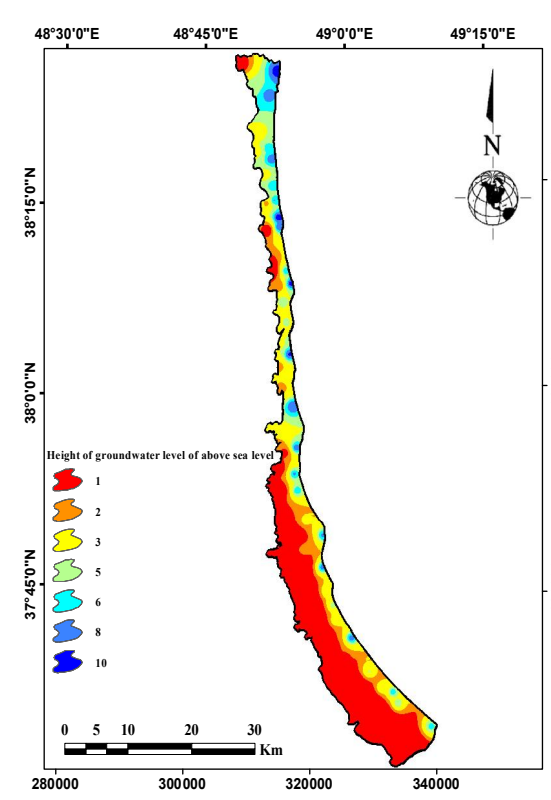

(ج)

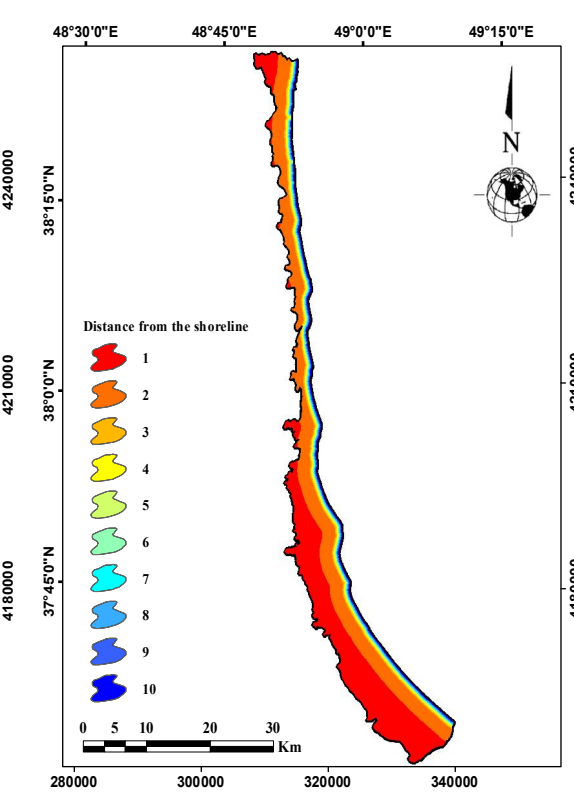

(ب)

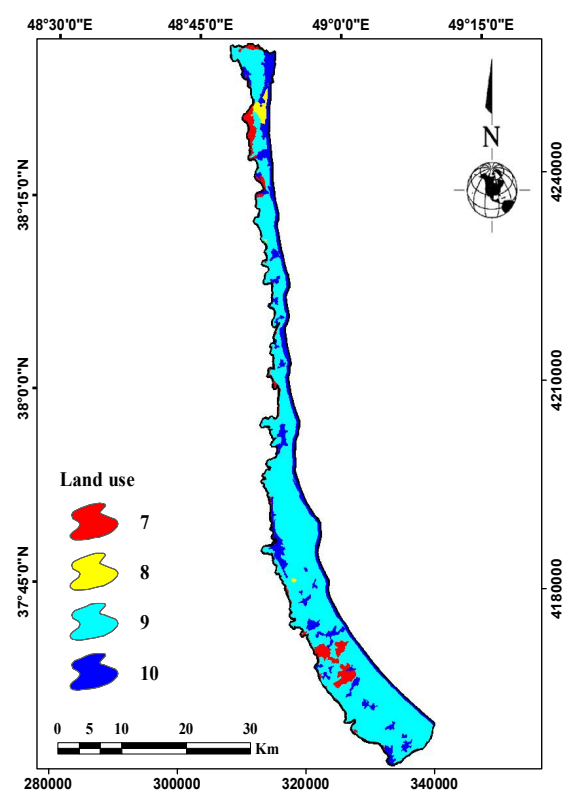

(الف)

شكل 9. نقشههاى: الف) كاربرى اراضى، ب) فاصله تا ساحل و ج) اختلاف تراز سطح آب زيرزمينى با سطح آب دريا

عظيمى از محيط غير اشـباع آبخــوان را تشـكيل مسىدهنــد و در

ناحيه مركزى محدوده مطالعاتى سهم ذرات ماسه بيشتر است.

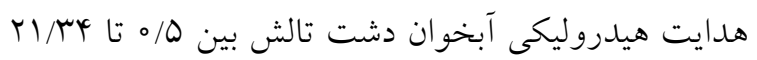

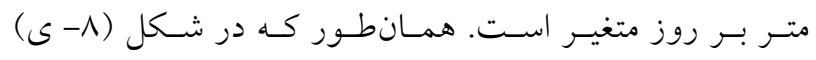

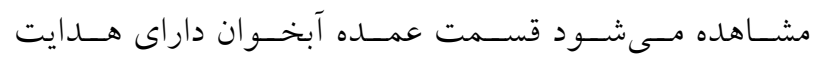

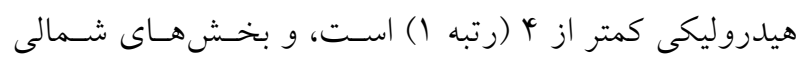

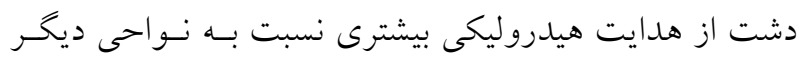
برخوردار هستند.

تحليل نقشه هاى بهنهبندى پيارامترهـاى DRASTIC اصـلاح

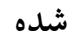
طبق نقشه يُهنهبندى اين يـارامتر در شـكل (9- الـف) كـاربرى

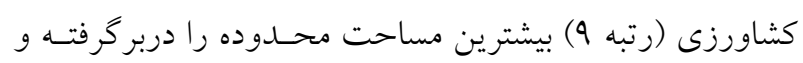

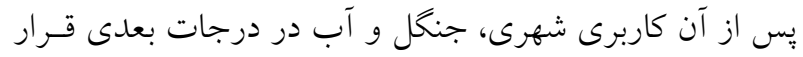

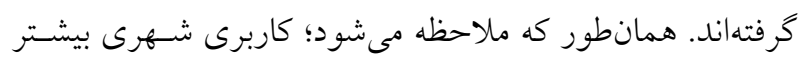
در نوار ساحلى و حاشيههاى اين دشت قرار كرفته است.

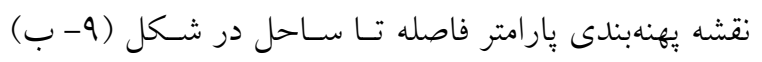

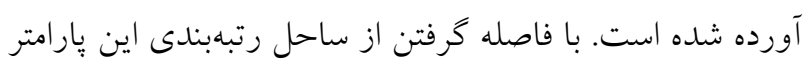

كه آبخوان دشت تالش بهصورت متناوب از ذرات ريزدانه نظيـر رس و سيلت تا ذرات درشتتر شن و ماسه با درصد بيشتر در قسمت شمالى، تشكيل شده است.

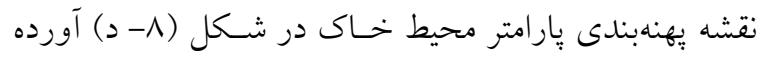
شده است. بافت خاك در بخشهـاى مختلـف دشـت متفـاوت

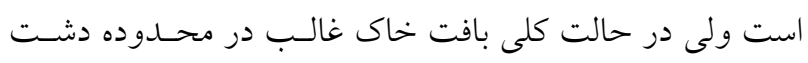

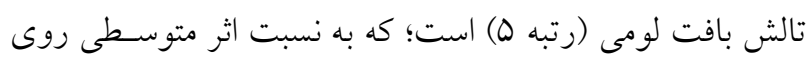
آسيب يذيرى دارد. شيب منطقه بين صفر تا س

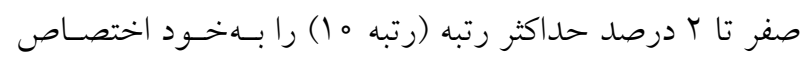

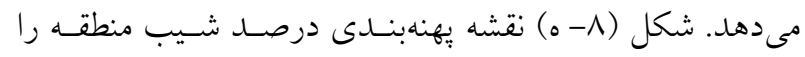
نشان مى دها. ملاحظه مى شود كه شـيب در منطقـهـ كـم بــوده و

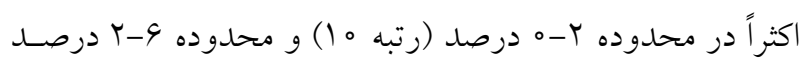

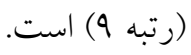
بافت رسوبات در محيط غير اشباع بين رس تا شـن و ماسـه

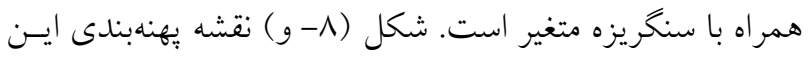
يارامتر را نشان مى دهد. همانطور كـه ملاحظـه مسى شـود ذرات

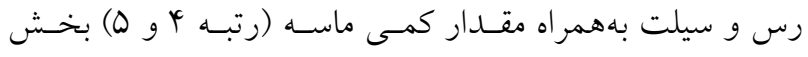


جدول r. تحليل آمارى آناليز حساسيت حذف تك نقشه

\begin{tabular}{|c|c|c|c|c|c|}
\hline \multicolumn{5}{|c|}{ شاخص تغييرات (\%) } & \multirow[t]{2}{*}{ يارامتر حذف شده } \\
\hline ضريب تغييرات (٪) & انحر اف معيار & حداكث & حداقل & ميانخين & \\
\hline & & & & & DRASTIC \\
\hline$\Delta \circ / V Y^{4}$ & $1 / T Y$ & $0 / 90$ & $0 / 0 Y$ & $T / 4 Y$ & $\mathrm{D}$ \\
\hline$\Delta T / Y T$ & $1 / 1 Y$ & $9 / \mu Y$ & $\circ$ & $T / 10$ & $\mathrm{R}$ \\
\hline $101 / 01$ & $1 / 09$ & $V / T G$ & 。 & $1 / 00$ & A \\
\hline$M / T H$ & $1 / T \Lambda$ & $9 / 00$ & 。 & $1 / 49$ & S \\
\hline$\Lambda V / T^{K}$ & $1 / 49$ & $9 / 40$ & 。 & $1 / N 0$ & $\mathrm{~T}$ \\
\hline$V Y / \circ 9$ & $\circ / \Lambda \mathrm{V}$ & $4 / 19$ & $\circ$ & $\mid / T 1$ & I \\
\hline $11 / 9 Y^{r}$ & $1 / 0 \wedge$ & $\Lambda / \circ V$ & 。 & $1 / 94$ & $\mathrm{C}$ \\
\hline & & & & & DRASTIC اصلاح شده \\
\hline $94 / 49$ & $0 / 19$ & $\Delta / \mu T$ & $\circ$ & $1 / \pi 0$ & $\mathrm{D}$ \\
\hline $90 / \circ V$ & $\circ / \sqrt{ } 9$ & $4 / 90$ & $\circ$ & $\mid / T 1$ & $\mathrm{R}$ \\
\hline$\Lambda \circ / r \Lambda$ & $\circ / \Lambda \mathrm{V}$ & $\Lambda / \Delta 9$ & $\circ$ & $1 / 09$ & A \\
\hline$\Lambda \circ / Y_{0}$ &.$/ 90$ & $V / T \wedge$ & $\circ$ & $1 / 19$ & S \\
\hline$\Lambda \mu / \circ \Lambda$ & $1 / \circ \wedge$ & $9 / 11$ & $\circ$ & $1 / \mu \circ$ & $\mathrm{T}$ \\
\hline$V Q / 9 V$ & $\circ / \sqrt{ } 9$ & $\Lambda / \Delta T$ & $\circ$ & $1 / 04$ & I \\
\hline $11 / 49$ & $1 / \circ V$ & N/DY & $\circ$ & $1 / T$ & $\mathrm{C}$ \\
\hline $91 / 14$ &.$/ 91$ & $4 / v q$ & $\circ$ & $1 / 9 \circ$ & $\mathrm{Lu}^{*}$ \\
\hline$V q / 9 T$ & $\circ / N Q$ & 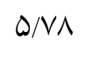 & $\circ$ &.$/ 94$ & $\mathrm{Di}^{*}$ \\
\hline$\Lambda 9 / 00$ & $\circ / \Lambda \mathrm{V}$ & G/NF & 。 & $1 / 01$ & $\mathrm{Le}^{*}$ \\
\hline
\end{tabular}

فاصله تا ساحل، :Li": اختلاف تراز سطح آب زيرزمينى با سطح آب دريا و Lu"

يستابى (D) در روش DRASTIC و حذف يـارامتر كـاربرى

اراضسى (Lu) در روش DRASTIC اصـالاح شــده بيشـتر از

ساير ويارامترها است، زيرا متوسط تغييـر شـاخص بـهـ ترتيـبـ

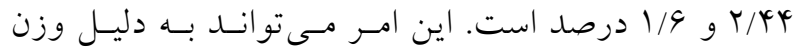

تئوريك بالا براى اين دو يارامتر باشد. علاوه بر اين، شاخص

نسبت بـه حـذف وِار امترهــاى تغذيسه خـالص و DRASTIC

هدايت هيدرليكى (به ترتيب بـا شـاخص تغييسرات ميـانخين

ه/l و r/9r درصد) و شـاخص DRASTIC اصـلاح شـده

نسبت به حذف يار امترهاى عمق تا سـطح ايستابى، هــدايت

هيدروليكى و تويسو گر افى (بـه ترتيـب بــا شـاخص تغييـرات

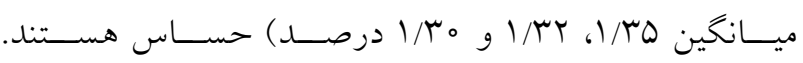

كمتر شده بهطورى كه بيشتر محدوده آبخوان در فاصله بـيش از هم متر (رتبه او Y) از نوار ساحلى واقع شده است. طبق شكل (9- ج) در نواحى جنوبى محدوده مورد بررسى اختلاف تراز بيش از هب متر (رتبه ()) بوده و در نواحى سـاحلى (غرب محدوده مورد مطالعه) اين مقدار تا نزديك به زير ب متـر كاهش مى تحليل نتايج آناليز حساسيت آناليز حساسيت حذف تك نقشه (جدول r) نشان مىدهد كه بـا توجـهه بـهـ تغييـرات شـاخص وَارامترهـا، تغييـر شـاخص

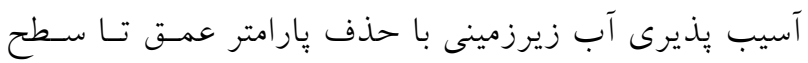


جدول f. تحليل آمارى آناليز حساسيت حذف جند نقشه

\begin{tabular}{|c|c|c|c|c|c|}
\hline \multicolumn{5}{|c|}{ شاخص تغييرات (\%) } & \multirow[t]{2}{*}{ يُارامترهاى استفاده شده } \\
\hline ضريب تغييرات (.) & انحر اف معيار & حداكثر & حداقل & ميانخين & \\
\hline & & & & & DRASTIC \\
\hline$V N / r)$ & $0 / r 1$ & $0 / 94$ & $\circ$ & $0 / r V$ & DRSTIC \\
\hline 9N/19 & $\circ / \Delta T^{4}$ & $r / 4 q$ & $\circ$ & $\circ / v 9$ & DRSTC \\
\hline $91 / 49$ & $0 / N \mid$ & $r / \Delta V$ & 。 & $|/ \Gamma|$ & DRTC \\
\hline$r \Lambda / \mu K$ & $1 / T V$ & $N / T$ & $1 / \pi V$ & $V / \& V$ & $\mathrm{DRC}$ \\
\hline $10 / 04$ & $1 / 19$ & $\mid N / \circ V$ & V/VG & $\mid r / T V$ & DR \\
\hline$\mu_{1 / N}$ & $r / \mu q$ & $r / \Delta r$ & 。 & $\mid r / N F$ & $\mathrm{D}$ \\
\hline & & & & & DRASTIC اصلاح شده \\
\hline$\Delta \Delta / \Gamma \Lambda$ & $\circ / T V$ & $0 / 9 T$ & $\circ$ & $0 / 49$ & DRASTIC_LuLe \\
\hline$V T / 90$ & $0 / 9 r$ & $r / \circ D$ & 。 & $\circ / \wedge 9$ & DRASTIC_Lu \\
\hline VQ/Tr & $0 / 91$ & T/MT & 。 & $\circ / \wedge 1$ & DRASTC_Lu \\
\hline$V \pi / r_{0}$ & $\circ / \mathrm{VV}$ & $r / \circ \Lambda$ & $\circ$ & $1 / \circ 0$ & DRSTC_Lu \\
\hline$Y 4 / 09$ & $1 / \circ r$ & 0 & 。 & $r / \Gamma)$ & DRTC_Lu \\
\hline GT/NT &.$/ 9 r$ & $\varphi / 4 \varphi$ & $\circ$ & $1 / 49$ & DTC_Lu \\
\hline MI/GY & $1 / \pi r$ & $\mathrm{~V} / \mathrm{VQ}$ & $1 / 0 r$ & $r / \wedge 9$ & DC_Lu \\
\hline IV/A。 & $1 / N V$ & $10 / \wedge r$ & $\Delta / 9 \Lambda$ & $9 / 94$ & D_Lu \\
\hline ro/VA & T/TQ & 19/1。 & $\Delta / \mu r$ & $10 / 19$ & $\mathrm{Lu}$ \\
\hline
\end{tabular}

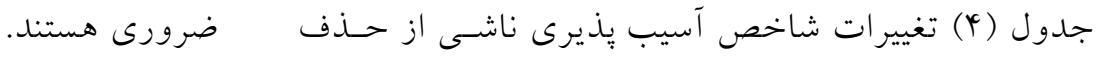

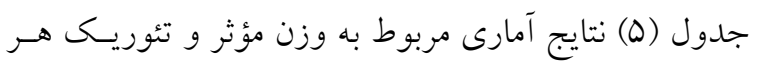

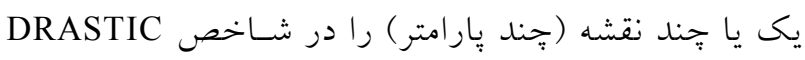

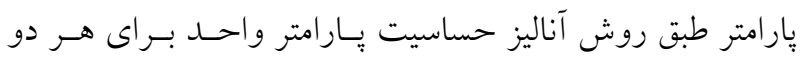
و DRASTIC اصلاح شده نشان مى دهد. حذف نقشه ها بـر

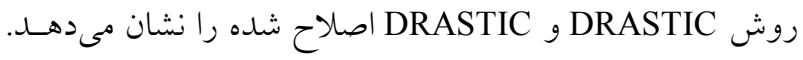

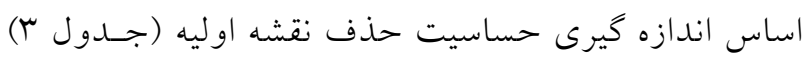
طبق جدول در روش DRASTIC يارامترهـاى عمـق تـا سـطح

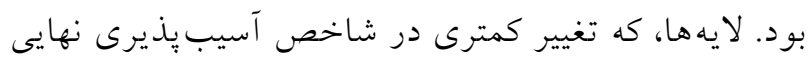

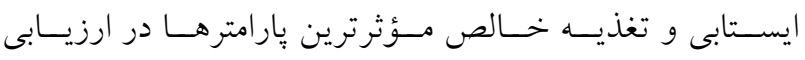

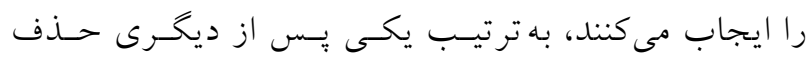

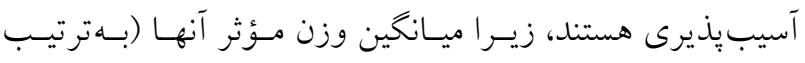

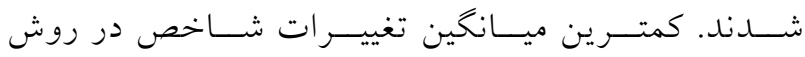

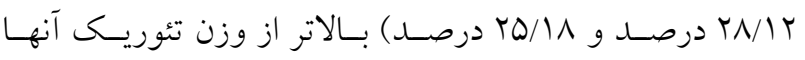
است. همخنين وزن مؤثر تويوكرافى و محيط آبخوان نسبت بـهـ

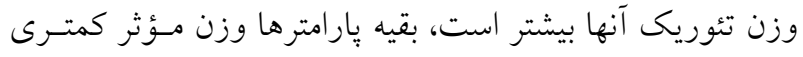

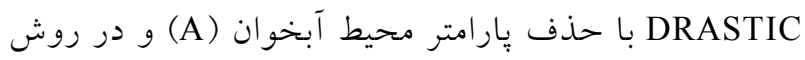

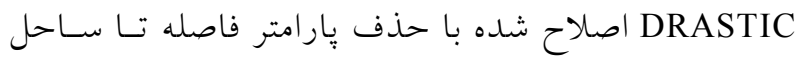

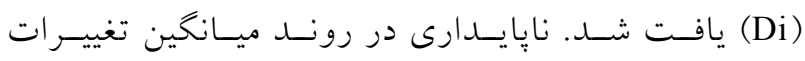

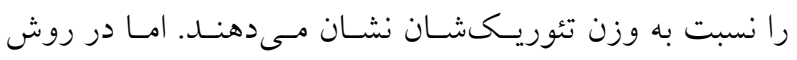

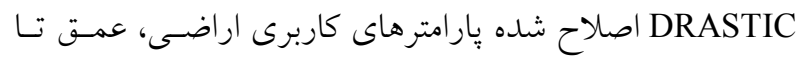

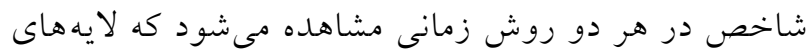

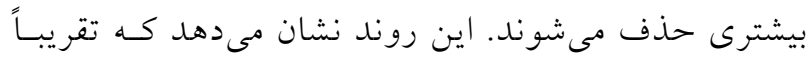

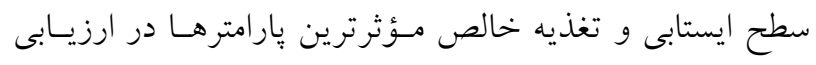

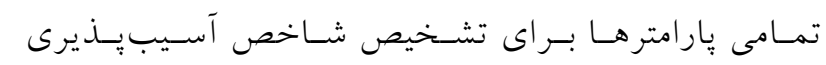


جدول ه. تحليل آمارى آناليز حساسيت تك بِارامترى

\begin{tabular}{|c|c|c|c|c|c|c|c|}
\hline \multicolumn{5}{|c|}{ وزن مؤثر (\%) } & \multirow[t]{2}{*}{ وزن تئوريك (.) } & \multirow[t]{2}{*}{ وزن تئوريك } & \multirow[t]{2}{*}{ 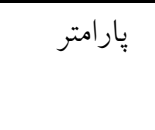 } \\
\hline ضريب تغييرات (.) & انحراف معيار & حداكثر & حداقل & ميانكين & & & \\
\hline $10 / 9 \pi$ & $\varphi / 40$ & rV/Ar & $1 \% / \wedge 9$ & TN/IT & $Y I / N Y^{4}$ & 0 & $\begin{array}{c}\text { DRASTIC } \\
\text { D }\end{array}$ \\
\hline $10 / 10$ & $T / M$ & rG/NT & $1 / / 90$ & $r \Delta / \wedge \Lambda$ & $1 V / r q$ & $r$ & $\mathrm{R}$ \\
\hline $\mid \psi / 04$ & $1 / 91$ & $1 N / 90$ & N/VG & $1 \% / 09$ & $1 \% / \%$ & r & A \\
\hline$r q / 94$ & $1 / 19$ & $\mid r / 19$ & $r / 91$ & $9 / Y r$ & $\Lambda / V_{0}$ & r & $\mathrm{S}$ \\
\hline$r / \Delta T^{\prime}$ & $1 / 10$ & $9 / N 1$ & $0 / 91$ & $\Delta / V_{0}$ & $r / T \Delta$ & 1 & $\mathrm{~T}$ \\
\hline$|4 / 9|$ & $r / 99$ & $r Q / \bar{\varphi}$ & $|r / 0|$ & $M / Y_{0}$ & $r M / N^{4}$ & 0 & I \\
\hline \multirow[t]{2}{*}{$r q / 91$} & $1 / 19$ & $1 / 19$ & 1/v9 & $r / 91$ & $1 \% / \% 4$ & r & $\mathrm{C}$ \\
\hline & & & & & \multicolumn{3}{|c|}{ DRASTIC اصلاح شده } \\
\hline $\mid r / 4 \lambda$ & $r / 09$ & rq/Vq & $9 / 79$ & $1 N / 9 V$ & $1 \% / \wedge 9$ & 0 & $\mathrm{D}$ \\
\hline $1 T / T_{0}$ & 1/9r & $r M / \Lambda Y$ & $11 / 04$ & $10 / \wedge t$ & $11 / 11$ & $r$ & $\mathrm{R}$ \\
\hline $\mathrm{IV} / \circ \mathrm{V}$ & $1 / 44$ & $1 Y / 90$ & Y NT & $N / \varphi^{4}$ & 1/N & r & A \\
\hline$r r / 09$ & $\circ / 99$ & $\Lambda / A V$ & $1 / N$ & $r / r r$ & $\Delta / \Delta \varphi$ & r & $\mathrm{S}$ \\
\hline$r \circ / Q_{0}$ & $\circ / \Lambda \mu$ & $9 / 41$ & $0 / 40$ & $\varphi / \circ V$ & T/VA & 1 & $\mathrm{~T}$ \\
\hline $19 / 01$ & $1 / 91$ & $19 / 91$ & V/99 & $11 / D F$ & $1 \pi / \wedge 9$ & 0 & I \\
\hline$r \circ / 90$ & $\circ N^{4}$ & $\Delta / N V$ & $1 / 01$ & $1 / 10$ & N/Tr & $r$ & $\mathrm{C}$ \\
\hline $10 / \lambda r$ & T/TG & $r Q / \Lambda_{0}$ & $10 / \pi r$ & $r \circ / \wedge q$ & $1 \pi / 19$ & 0 & $\mathrm{Lu}$ \\
\hline$\Delta N / 90$ & $r / T r$ & $I V / V A$ & $I / N Y$ & $V / r G$ & $11 / 11$ & $r$ & Di \\
\hline$Y N / M$ & $r / r V$ & IV/TY & 1/Va & $9 / 199$ & $11 / 11$ & r & $\mathrm{Le}$ \\
\hline
\end{tabular}

مؤثرى است كه قبلاً به صورت كارشناسى به آن اختصاص داده

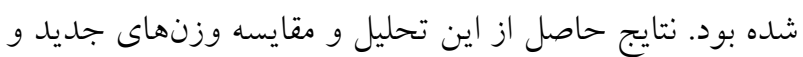

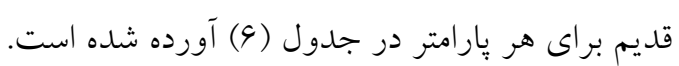
در حالت كلى از وزنهاى جديد ارائه شـــه بـــاى هـر روش

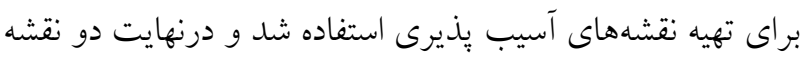

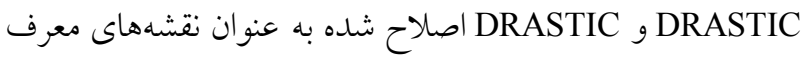
آسيب يذيرى آبخوان مورد بررسى انتخـاب شــند و نقشههــاى

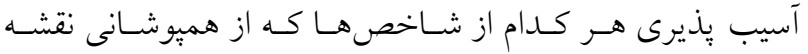
يارامترها با استفاده از روابط ا و Y حاصـل شـد، در شـكل (10)

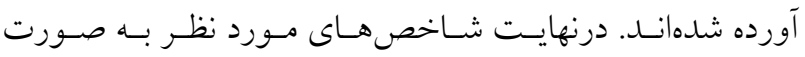

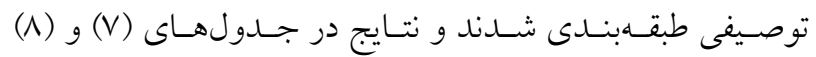

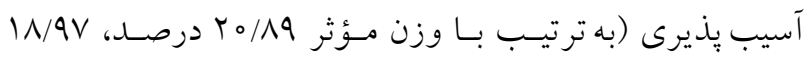

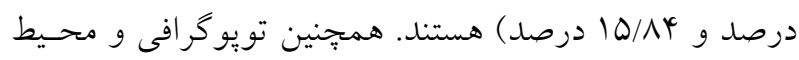

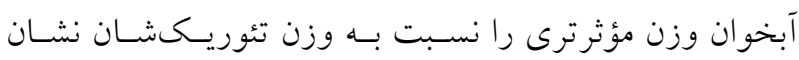
مى دهند. بقيه يارامترها داراى وزن مؤثر كمترى نسبت بـهـ وزن

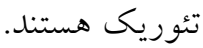
تحليل نقشههاى آسيبِيذيرى آبخوان دشت تالش

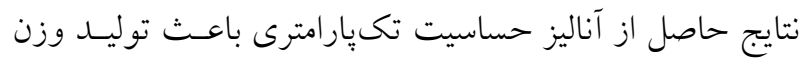
جديد براى هر يكى از يارامترها شد. بارامترهايى كه درصد وزن مؤثر بيشترى نسبت به درصد وزن تئوريكى دارند در رتبـهبنـدى فرى

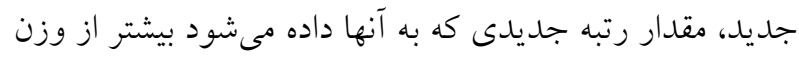


جدول و. نتايج تحليلى درصد وزن تئورى و درصد وزن مؤثر در شاخص DRASTIC و DRASTIC اصلاح شده

\begin{tabular}{|c|c|c|c|c|c|c|c|c|c|c|c|}
\hline & & & $\mathrm{C}$ & I & $\mathrm{T}$ & $\mathrm{S}$ & A & $\mathrm{R}$ & $\mathrm{D}$ & يّارامتر & \multirow{3}{*}{ DRASTIC } \\
\hline & & & $r$ & $\Delta$ & 1 & r & r & r & 0 & وزن قديم & \\
\hline & & & $0 / 91$ & $4 / 19$ & $|/ \mu|$ & $1 / 4 r$ & $r / \mu$ & $0 / V q$ & $G / 4 V$ & وزن جديد & \\
\hline $\mathrm{Le}$ & $\mathrm{Di}$ & $\mathrm{Lu}$ & $\mathrm{C}$ & I & $\mathrm{T}$ & $\mathrm{S}$ & A & $\mathrm{R}$ & $\mathrm{D}$ & يار امتر & \multirow{3}{*}{$\begin{array}{l}\text { DRASTIC } \\
\text { صلاح شده }\end{array}$} \\
\hline r & $r$ & 0 & $r$ & 0 & 1 & r & $r$ & $r$ & 0 & وزن قديم & \\
\hline$r / 4 \Lambda$ & $r / 90$ & V/OT &.$/ 90$ & $4 / 19$ & $1 / 49$ & I/OT & $r / \circ r$ & $\Delta / V 。$ & G/Ar & وزن جديد & \\
\hline
\end{tabular}
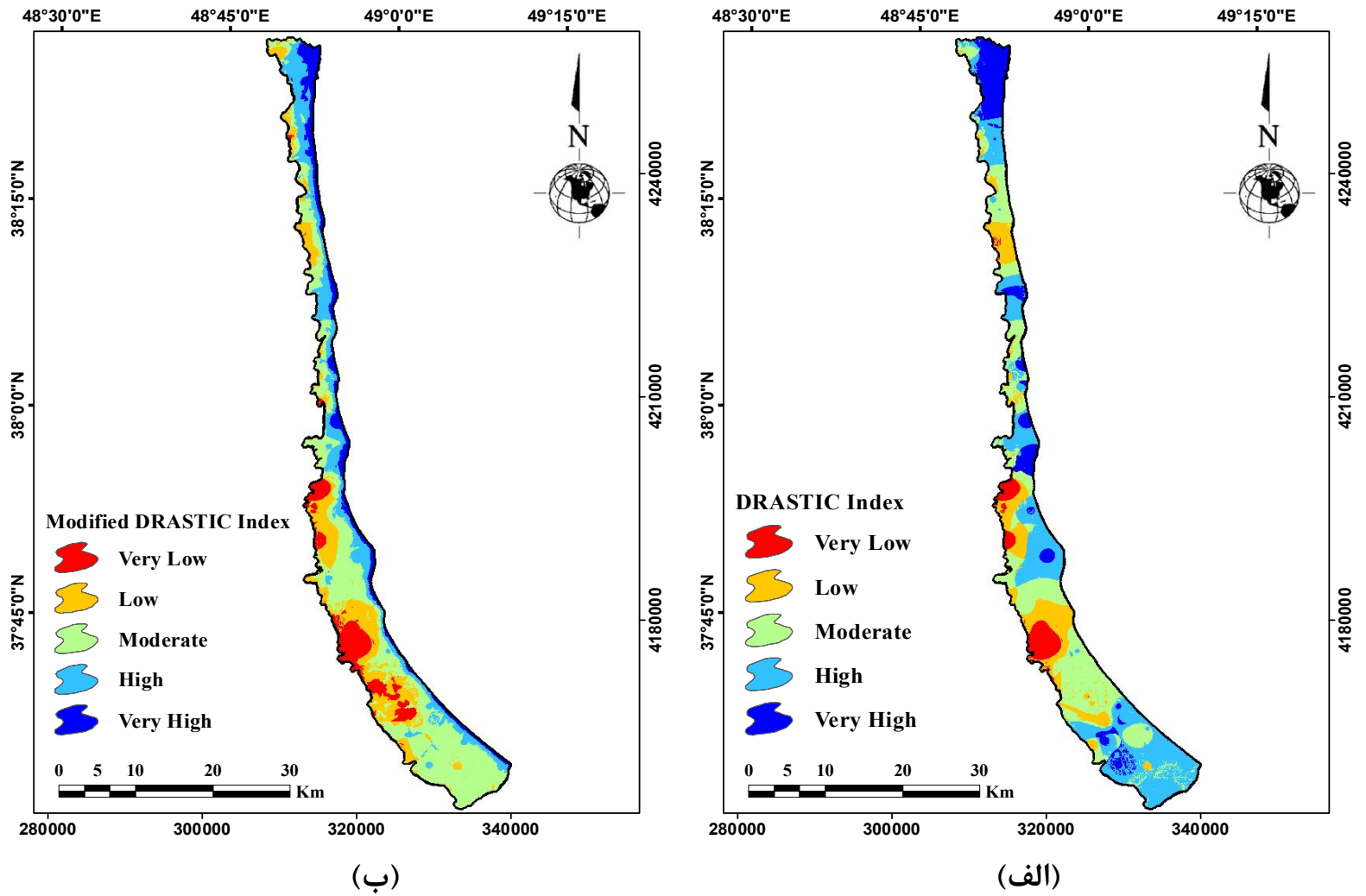

شكل • ا. نقشه آسيبذيرى آبخوان ساحلى تالش: الف) DRASTIC و ب) DRASTIC اصلاح شده

جدول V. طبقهبندى و مساحت مناطق آسيبذيذير آبخوان ساحلى تالش بهروش DRASTIC

\begin{tabular}{|c|c|c|c|}
\hline مساحت (.) & مساحت (km²) & محدوده & طبقه آسيبيذيرى \\
\hline $0 / 09$ & TS/99 & $\| K-1 k T$ & خيلى كم (Very low) \\
\hline $19 / 19$ & $\vee \wedge / \Delta \circ$ & $\mid Y Y-1 D D$ & كم (Low) \\
\hline$M T / 9 V$ & $10 \% / 91$ & $100-194$ & متوسط (Moderate) \\
\hline MT/g4 & $19 \pi / 10$ & $194-1 V$ & زياد (High) \\
\hline $1 Y / 94$ & GT/VA & $1 V r-19 T$ & خيلى زياد (Very high) \\
\hline 100 & $4 \wedge \% / 99$ & جمع & \\
\hline
\end{tabular}


جدول ^. طبقهبندى و مساحت مناطق آسيب يذير آبخوان ساحلى تالش بهروش DRASTIC اصلاحشده

\begin{tabular}{|c|c|c|c|}
\hline مساحت (.) & مساحت (km²) & محدوده & طبقه آسيبيذيرى \\
\hline $9 / \circ V$ & $k y / 01$ & MAG-YYT & خيلى كم (Very low) \\
\hline $19 / 19$ & $99 / 40$ & TYY-YMN & كم (Low) \\
\hline$+1 / V^{c}$ & $Y \circ Y / Y Y$ & rrN-ror & متوسط (Moderate) \\
\hline$r \circ / V Q$ & $100 / 94$ & $r \Delta \mu-r V T$ & زياد (High) \\
\hline$\Lambda / \Delta D$ & $41 / 40$ & TVM-rTY & خيلى زياد (Very high) \\
\hline 100 & $4 \wedge \% / 99$ & جمع & \\
\hline
\end{tabular}

نزديك بودن سطح آب زيرزمينى بـه سـطح زمسين در بيشـتر نواحى محدودهه مورد بررسى، تغذيه بيشتر در قسمت مركزى و شمال منطقه و تا حدى درشت دانه بودن بافت خـاك در محيط غيراشباع سبب آسيب يذيرى متوسط تا زيـاد و خيلى زياد در محدوده دشت تالش شده اسـت. همجنـين در روش اصـلاح شــده عمـق كـم آب زيرزمينس، تغذيسه آبخوان در قسمت هاى شمالى محسدوده، كـاربرى شـهرى در يارامتر نوع كاربرى اراضسى، كـم بـودن فاصـله تـاســاحل و

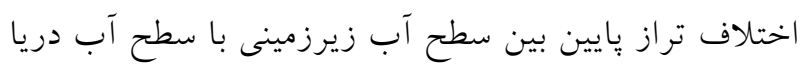

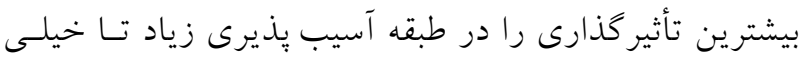
زياد در آبخوان دشت تـالش در روش اصـلاح شــده دارنـــ؛ بهورىى كه اكثر نو احى با كاربرى شهرى، فاصله تـا سـاحل زير ه هـه متـر و اخـتلاف تــراز كمتـر از ها متـر در محسدوده آسيب بذ بـرى زياد تـا خيلسى زيـاد روش اصـلاح شــده قـرار

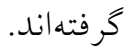
با توجه به نتايج آزمـون تحليـل همبسـتحى شـاخصهـا بـا دادهاى اندازهكيرى شده EC، ضـريب همبسـتكى بيرسـون در

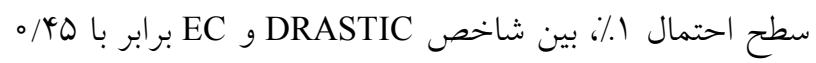

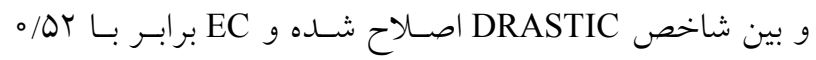

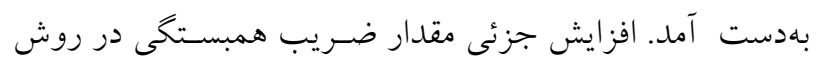
اصلاح شده را مى تـوان بـه اضـافه كـــدن يّرامترهـاى كـاربرى

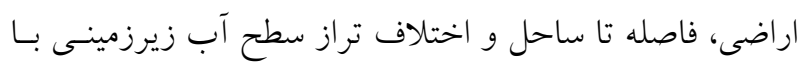
سطح آب دريا ربط داد.
آورده شـده اسـت. عسـد محاسـبه شـــه نشـاندهنــده ميـزان حساسيت سفره به آلوده شدن بوده به اين ترتيب كـه اعـداد بزرگتر تعيين كننده استعداد بيشتر آبخوان براى آلوده شــن

نتايج حاصـل از روش DRASTIC نشـان داد كـه مقـدار

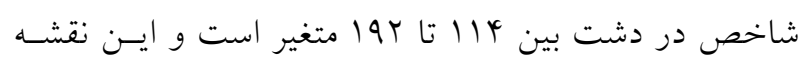
به ينج كلاس طبقهبندى شد. بدين ترتيب كه ه/O4ه درصد از

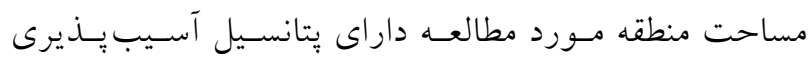
خيلى كم، 19/19 درصد داراى يتانسـيل آسـيب يـذيرى كـم،

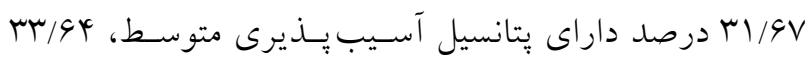

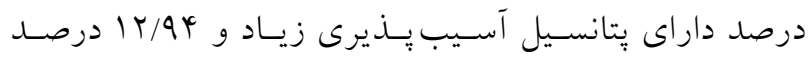
داراى يتانسيل آسيب بذّيرى خيلى زياد است. درصورتى كـه نتايج روش DRASTIC اصـلاح شــه نشـان داد كـه مقـدار

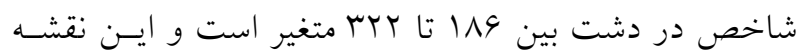
به ينج كاس طبقهبندى شد بدين ترتيب كه 9/०V درصسد از

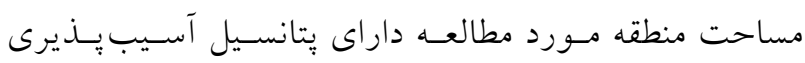
خيلى كم، 19/19 درصد داراى يتانسـيل آسـيب يـذيرى كـم،

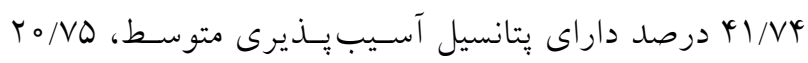
درصد داراى يتانسيل آسيب يذيرى زياد و N/Dه درصد داراى يتانسيل آسيب يذّيرى خيلى زياد است. در روش DRASTIC بيشترين مساحت آبخوان را طبقه آسيب يذيرى زياد با درصد

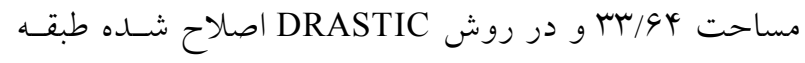

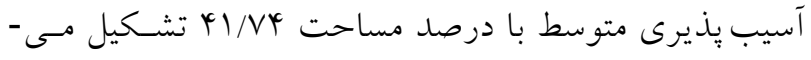
دهند. به طور كلى مسىتـوان گفـت كـه در روش DRASTIC 
كاربرىهاى شهرى در مناطق كاملاً آسيب يذذير قـرار كرفتـهانـد. تتيجه كيرى

بدين ترتيب نقشه آسيب يذيرى در شناسايى مناطقى كه احتمـال دارد نسبت به آلودكى آب هـاى زيرزمينسى نسـبت بـه يكـديخر

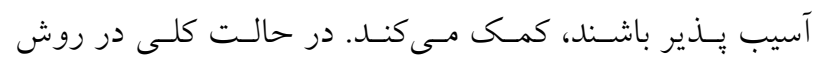
اصلاح شده درصد مساحت طبقات با آسيب يذيرى DRASTIC خيلى كم تا متوسط نسـبت بـه روش DRASTIC بيشـتر شـده

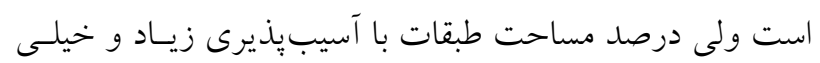
زياد آن كاهش يافته است.

نتايج حاصل از آناليز حساسيت تكىيـارامترى نشـان داد كـهـ بار امترهاى عمق تـا سـطح ايسـتابى و تغذيـه خـالص در روش DRASTIC و تغذيه خالص در روش DRASTIC اصـلاح شــه مـؤثرترين يار امترها در ارزيابى آسيب يذّيرى هسـتند. همجنــين بـر اسـاس آناليز حساسيت حذف نقشه، يارامترهاى عمق تا سطح ايستابى، تغذيه خالص و هدايت هيدروليكى در شـاخص DRASTIC و يار امترهاى كاربرى اراضى و عمق تا سطح ايستابى در شـاخص DRASTIC

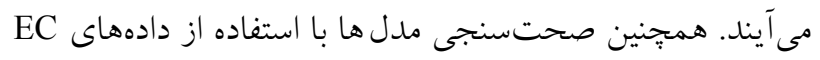
برترى DRASTIC اصلاح شده را نسبت به DRASTIC اصسلى

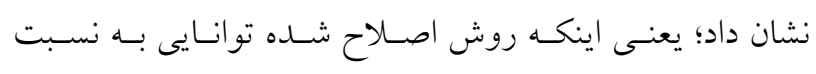
بيشترى در جهت نشان دادن شورى آب زيرزمينى دارد.

مــل DRASTIC يـك مــدل كمـى مـــيريتى بــراى ارزيــابى آسيب بذيرى آبخوان آب زيرزمينى بوده كه شامل V يارامتر مؤثر در انتقال آلودگى (عمق تا سطح ايستابى، تغذيه خالص، محسيط خاك، تويو گر افى، محيط آبخــوان، محسيط غيراشـباع و هـــايت

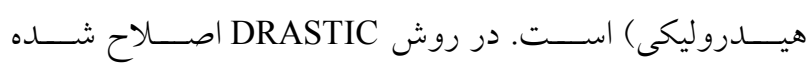

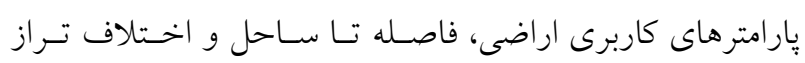
سطح آب زيرزمينى با سـطح دريـا نيـز دخالـت داده شـدهانـد.

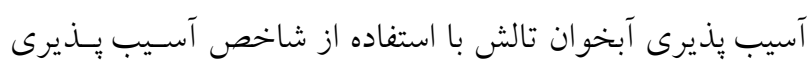

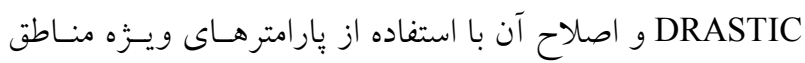

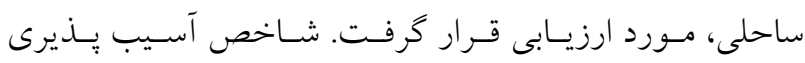
DRASTIC به يسنج كـلاس ب ب أl

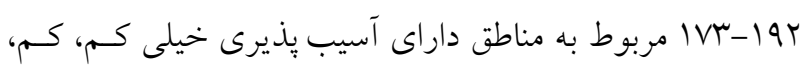
متوسط، زياد و خيلى زياد طبقهبندى مىشوند. همجنين شاخص

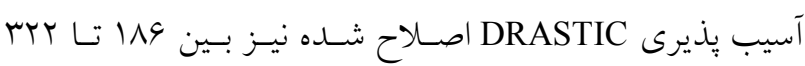
متغير بوده و به يـنج كـلاس بr

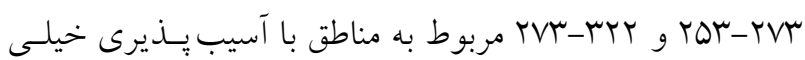
كم، كم، متوسط، زياد و خيلى زياد طبقهبنـدى مسىشـود. نقشـه يتانسيل آسيب يذيرى DRASTIC اصلاح شـده (شـكل 9- ب)

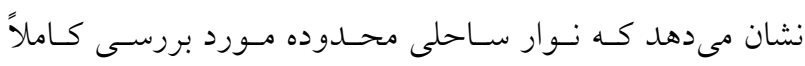
آسيب بِذير است. نقشه آسيب بذيرى نهايى نشان مى دهد كه اكثر

\section{منابع مورد استفاده}

1. Afonso, M. J., A. Pires, I. Helder and J. M. Chamine Marques. 2008. Aquifer Vulnerability Assessment of Urban Areas using a GIS-Based Cartography: Paranhos Groundwater Pilot Site, Porto, NW Portugal.

2. Ali Khan, M. M., R. Umar and H. Lateh. 2010. Assessment of aquifer vulnerability in parts of Indo Gangetic plain, India. International Journal of the Physical Sciences 5(11): 1711-1720.

3. Aller, L., T. Bennet, J. H. Lehr, R. J. Petty and G. Hackett. 1987. DRASTIC: a Standardized System for Evaluating Groundwater Pollution Potential Using Hydrogeological Settings. EPA/600/2-87/035, US EPA, Ada, OK, USA.

4. Antonakos, A. K. and N. J. Lambrakis. 2007. Development and testing of three hybrid methods for the assessment of aquifer vulnerability to nitrates, based on the drastic model, an example from NE Korinthia, Greece. Journal of Hydrology 333(2-4): 288-304.

5. Barber, C., L. E. Bates, R. Barron and H. Allison. 1993. Assessment of the relative vulnerability of groundwater to pollution: A review and background paper for the conference workshop on vulnerability assessment. Journal of Australian Geology and Geophysics 14(2-3): 147-154. 
6. Boughriba, M., A. Barkaoui, Y. Zarhloule, Z. Lahmer, B. El Houadi and M. Verdoya. 2010. Groundwater vulnerability and risk mapping of the Angad transboundary aquifer using DRASTIC index method in GIS environment. Arabian Journal of Geosciences 3: 207-220.

7. Chachadi, A. G., 2005. Seawater intrusion mapping using modifed GALDIT indicator model-case study in Goa. Jalvigyan Sameeksha 20: 29-45.

8. Kardan Moghaddam, H., F. Jafari and S. Javadi. 2015. Evaluation vulnerability of coastal aquifer via GALDIT model and comparison with DRASTIC index using quality parameters. Hydrological Sciences Journal 62(1): 137146.

9. Kazakis, N. and K. S. Voudouris. 2015. Groundwater vulnerability and pollution risk assessment of porous aquifers to nitrate: modifying the drastic method using quantitative parameters. Journal of Hydrology 525: 13-25.

10. Khoshdooz, N., H. Babazadeh, S. H. Tabatabaei and M. Naderi. 2013. Modifying DRASTIC model to determine groundwater vulnerability in a coastal region. In: Water and Soil Resources Conservation 3(1): 19-31.

11. Lodwick, W. A., W. Monson and L. Svoboda. 1990. Attribute error and sensitivity analysis of map operations in geographical information systems: suitability analysis. International Journal of Geographic Information System 4(4):413-428.

12. Mahdavi, A. and H. Zare. 2016. Determination of aquifer vulnerability potential based on DRASTIC and FUZZY logic models (case study: Hamedan- Bahar Plain). Water and Soil Science 26(1): 1-17.

13. Margat, J. 1968. Groundwater Vulnerability to Contamination, Bases de la Cartographie, Doc. 68 SGC 198 HYD, BRGM, Orleans.

14. Michalopoulos, D. and E. Dimitriou. 2018. Assessment of pollution risk mapping methods in an Eastern Mediterranean catchment. Journal of Ecological Engineering 19(1): 55-68.

15. Momejian, N., M. Abou Najm, I. Alameddine and M. El-Fadel. 2018. Can groundwater vulnerability models assess seawater intrusion? Environmental Impact Assessment Review 75: 13-26.

16. Mondal, N. C., S. Adike, V. S. Singh, S. Ahmed and K. V. Jayakumar. 2016. Determining shallow aquifer vulnerability by the DRASTIC model and hydrochemistry in granitic terrain, southern India. Journal of Earth System Science 126: 89.

17. Mousavi, F., M. Yaghoubi and M. Chitsazan. 2016. Land use management by assessing aquifer vulnerability in Khovayes plain using the DRASTIC and SINTACS models. Journal of Water and Wastewater 3: 75-79.

18. Napolitano, P. and A. G. Fabbri. 1996. Single-parameter sensitivity analysis for aquifer vulnerability assessment using DRASTIC and SINTACS. Proceedings of the Vienna conference on HydroGIS 96: Application of geographic information systems in hydrology and water resources management, IAHS Pub 235: 559-566.

19. Neshat A, Pradhan B. 2017. Evaluation of groundwater vulnerability to pollution using DRASTIC framework and GIS. Arabian Journal of Geosciences 10(22): 501.

20. Oroji, B. and E. Solgi. 2016. Vulnerability assessment of Asadabad (Hamadan) plain groundwater by GIS. Environmental Sciences 14(1): 91-104.

21. Saidi, S., S. Bouri and H. B. Dhia. 2011. Sensitivity analysis in groundwater vulnerability assessment based on GIS in the Mahdia-Ksour Essaf aquifer, Tunisia: a validation study. Hydrological Sciences Journal 56(2): 288-304.

22. Xiaoyu, W., L. Bin and M. Chuanming. 2018. Assessment of groundwater vulnerability by applying the modified DRASTIC model in Beihai City, China. Environmental Science and Pollution Research 21: 1-5. 


\title{
Qualitative Assessment of the Coastal Plain of Talesh using the Modified DRASTIC Vulnerability Method
}

\author{
H. Mahmoudpour ${ }^{1}$, S. Janatrostami2*, A. Ashrafzadeh ${ }^{3}$
}

(Received: April 29-2019; Accepted: January 1-2020)

\begin{abstract}
Given the fact that the DRASTIC index is ineffective in addressing the saltwater uprising issue in coastal plains, in the present study, three factors including land use, distance to shoreline, and differences between groundwater and sea level were added to the DRASTIC index. The proposed modification to DRASTIC was validated using the measured electrical conductivity (EC) data gathered from groundwater monitoring wells throughout the Talesh Plain. The results showed that the coefficient of correlation between the map of EC over the region and the modified DRASTIC was 0.52, while for the original DRASTIC, the coefficient was 0.45 , thereby implying a stronger relationship between EC and the modified DRASTIC in the Talesh Plain. Sensitivity analysis also showed that DRASTIC and the modified DRASTIC were the most sensitive to, respectively, depth to groundwater (D) and land use (Lu). According to the single-parameter sensitivity analysis results, depth to water table and net recharge were the most effective parameters in DRASTIC, whereas the modified DRASTIC was the most sensitive to land use and depth to groundwater. It could be concluded that modifying the DRASTIC index would result in decreasing the area of very high and high vulnerable classes, and the area classified as low and moderate vulnerable could be increased.
\end{abstract}

Keywords: Sensitivity analysis, Groundwater, Land use, Validation.

1. Department of Water Engineering, College of Agricultural Sciences, University of Guilan, Rasht, Iran.

*: Corresponding author, Email: janatrostami@guilan.ac.ir 